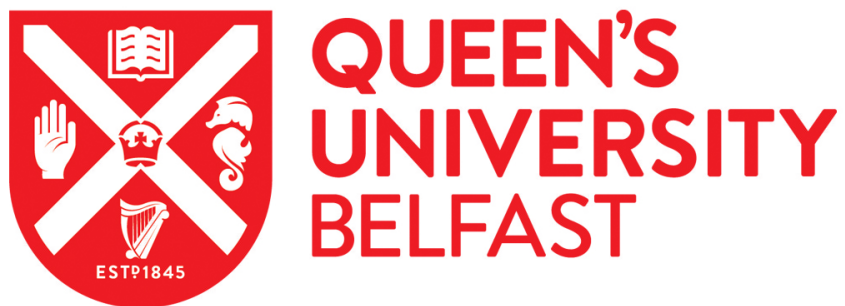

\section{Soil-Geochemical Factors controlling the Distribution and Oral Bioaccessibility of Nickel, Vanadium and Chromium in Northern Ireland Soils}

Palmer, S., Cox, S., McKinley, J., \& Ofterdinger, U. (2014). Soil-Geochemical Factors controlling the Distribution and Oral Bioaccessibility of Nickel, Vanadium and Chromium in Northern Ireland Soils. Applied Geochemistry, 51, 255-267. https://doi.org/10.1016/j.apgeochem.2014.10.010

Published in:

Applied Geochemistry

Document Version:

Peer reviewed version

Queen's University Belfast - Research Portal:

Link to publication record in Queen's University Belfast Research Portal

\begin{abstract}
Publisher rights
This is the author's version of a work that was accepted for publication in Applied Geochemistry. Changes resulting from the publishing process, such as peer review, editing, corrections, structural formatting, and other quality control mechanisms may not be reflected in this document. Changes may have been made to this work since it was submitted for publication. A definitive version was subsequently published in Applied Geochemistry, Vol 51 (Dec 2014) 10.1016/j.apgeochem.2014.10.010
\end{abstract}

\section{General rights}

Copyright for the publications made accessible via the Queen's University Belfast Research Portal is retained by the author(s) and / or other copyright owners and it is a condition of accessing these publications that users recognise and abide by the legal requirements associated with these rights.

\section{Take down policy}

The Research Portal is Queen's institutional repository that provides access to Queen's research output. Every effort has been made to ensure that content in the Research Portal does not infringe any person's rights, or applicable UK laws. If you discover content in the Research Portal that you believe breaches copyright or violates any law, please contact openaccess@qub.ac.uk. 


\section{Accepted Manuscript}

Soil-geochemical factors controlling the distribution and oral bioaccessibility of nickel, vanadium and chromium in soil

Sherry Palmer, Siobhan F. Cox, Jennifer M. McKinley, Ulrich Ofterdinger

PII:

S0883-2927(14)00242-X

DOI: http://dx.doi.org/10.1016/j.apgeochem.2014.10.010

Reference: AG 3344

To appear in:

Applied Geochemistry

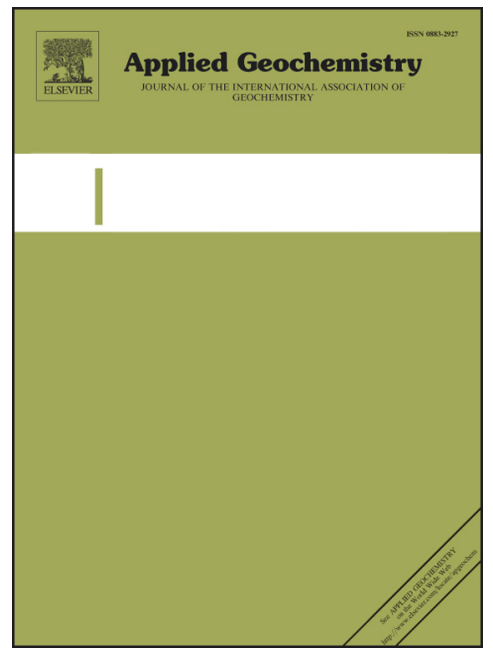

Please cite this article as: Palmer, S., Cox, S.F., McKinley, J.M., Ofterdinger, U., Soil-geochemical factors controlling the distribution and oral bioaccessibility of nickel, vanadium and chromium in soil, Applied Geochemistry (2014), doi: http://dx.doi.org/10.1016/j.apgeochem.2014.10.010

This is a PDF file of an unedited manuscript that has been accepted for publication. As a service to our customers we are providing this early version of the manuscript. The manuscript will undergo copyediting, typesetting, and review of the resulting proof before it is published in its final form. Please note that during the production process errors may be discovered which could affect the content, and all legal disclaimers that apply to the journal pertain. 


\title{
SOIL-GEOCHEMICAL FACTORS CONTROLLING THE DISTRIBUTION AND ORAL BIOACCESSIBILITY OF NICKEL, VANADIUM AND CHROMIUM IN SOIL
}

\author{
Sherry Palmer ${ }^{*}$,, Siobhan F. Cox ${ }^{\mathrm{a}}$, Jennifer M. McKinley ${ }^{\mathrm{b}}$ and Ulrich Ofterdinger ${ }^{\mathrm{a}}$ \\ ${ }^{a}$ School of Planning, Architecture and Civil Engineering; Queen's University Belfast, BT9 5AG, UK \\ ${ }^{b}$ School of Geography, Archaeology and Palaeoecology; Queen's University Belfast, BT7 1NN, UK \\ *Corresponding author; spalmer04@qub.ac.uk, Tel. +44 (028) 9097 5606, Fax +44 (028) 90974278 \\ Additionale-mail addresses; s.cox@qub.ac.uk, j.mckinley@qub.ac.uk,u.ofterdinger@qub.ac.uk
}

\begin{abstract}
Geogenic nickel $(\mathrm{Ni})$, vanadium $(\mathrm{V})$ and chromium $(\mathrm{Cr})$ are present at elevated levels in soils in Northern Ireland. Whilst $\mathrm{Ni}, \mathrm{V}$ and $\mathrm{Cr}$ total soil concentrations share common geological origins, their respective levels of oral bioaccessibility are influenced by different soil-geochemical factors. Oral bioaccessibility extractions were carried out on 145 soil samples overlying 9 different bedrock types to measure the bioaccessible portions of $\mathrm{Ni}, \mathrm{V}$ and $\mathrm{Cr}$. Principal component analysis identified two components (PC1 and PC2) accounting for 69\% of variance across 13 variables from the Northern Ireland Tellus Survey geochemical data. PC1 was associated with underlying basalt bedrock, higher bioaccessible $\mathrm{Cr}$ concentrations and lower Ni bioaccessibility. PC2 was associated with regional variance in soil chemistry and hosted factors accounting for higher $\mathrm{Ni}$ and $\mathrm{V}$ bioaccessibility. Eight per cent of total $\mathrm{V}$ was solubilised by gastric extraction on average across the study area. High median proportions of bioaccessible $\mathrm{Ni}$ were observed in soils overlying sedimentary rock types. Whilst $\mathrm{Cr}$ bioaccessible fractions were low $(\max =5.4 \%)$, the highest measured bioaccessible $\mathrm{Cr}$ concentration reached $10.0 \mathrm{mg} \mathrm{kg}^{-1}$, explained by factors linked to $\mathrm{PC} 1$ including high total $\mathrm{Cr}$ concentrations in soils overlying basalt bedrock.
\end{abstract}

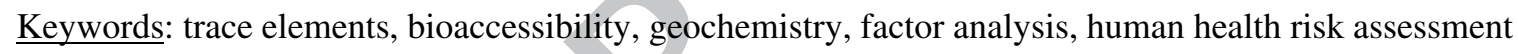




\subsection{Introduction}

In Northern Ireland, nickel (Ni), vanadium (V) and chromium (Cr) are present in soils at high total concentrations, in some cases exceeding available statutory soil guideline values (SGVs) or generic assessment criteria (Environment Agency, 2009; Nathaniel et al., 2009). SGVs are intended for use as screening values; significant harm may not necessarily be present when a contaminant exceeds its SGV, but regulators may wish to seek additional evidence to determine if there is a high probability of significant harm to receptors from soil contaminant exposure under such circumstances (DEFRA, 2012).

Refining the human health risk assessment process with respect to oral exposure to soil borne contaminants plays an important role in sustainable development approaches. Informed land management practices and accurate risk communication can save local councils, land owners, and developers millions of pounds in remediation costs, in turn preserving natural soil resources (NERC, 2012). Soil bioaccessibility testing can be applied to complement a lines-of-evidence approach when assessing health risks from oral soil contaminant exposure (CIEH, 2009; DEFRA, 2012). In terms of risk estimation, in vitro oral bioaccessibility testing reduces reliance on total contaminant concentrations in soil, an approach which commonly will overestimate health risks due to the well-accepted concept that $100 \%$ of soil contamination is rarely bioavailable to receptors when ingested (Ruby et al., 1999; CIEH, 2009). Compared to in vivo animal bioavailability studies, in vitro testing is also less costly and can be completed in a shorter time frame while avoiding the ethical concerns of using live animals in research.

Over the past two decades, a considerable amount of effort has been invested across the scientific community in developing and validating a suitable standardised extraction method for estimating human oral contaminant bioaccessibility in vitro (Ruby et al., 1996; Ruby et al., 1999; Oomen et al., 2003; Wragg and Cave, 2003; Van de Weile et al., 2007; Wragg et al., 2009; NERC, 2012). The Unified BARGE (Bioaccessibility Research Group of Europe) Method (UBM) is a standardised physiologically based extraction technique which has been subjected to comprehensive inter-laboratory trials and validated for arsenic (As), lead (Pb) and cadmium (Cd) using in vivo swine data (Caboche, 2009; Wragg et al., 2011; Denys et al., 2012).

Previous trace element bioaccessibility research in Northern Ireland has shown that oral bioaccessibility is not primarily a function of total trace element concentrations in soil (Barsby et al, 2012; Palmer et al., 2013; Cox et al., 2013), diminishing the suitability of reliance on total soil contaminant concentrations as a driver for contaminated land management decisions. Following from these findings, specific geochemical factors accounting for the variability in trace element bioaccessibility across the country 
require further investigation. Correlation studies exploring relationships between trace element bioaccessibility and other geochemical variables found statistically significant relationships which varied across different underlying bedrock types (Palmer et al., 2013; Cox et al. 2013). For example, sulphur measured as sulphur trioxide $\left(\mathrm{SO}_{3}\right)$ and loss on ignition (LOI) data showed strong positive associations with $\mathrm{Ni}$ and $\mathrm{V}$ bioaccessibility throughout Northern Ireland, whilst calcium appeared to exert either positive or negative influences over bioaccessibility depending upon the underlying bedrock type (Palmer et al., 2013).

Although several statistically significant intrinsic correlations between trace element bioaccessibility and a number of other geochemical variables have been previously confirmed, specific soil-geochemical associations are difficult to identify from correlation analysis alone. This paper therefore aims to more explicitly identify such soil-geochemical associations on a regional scale through a combined analysis approach. Exploratory data analysis (EDA), factor analysis and geostatistics were used to validate and identify common sources of variability across two data sets (Gooaverts, 1992; Abollino et al., 2011; Candeias et al., 2011; Giacomino et al., 2011), supporting the research aim of identifying geochemical factors that account for variability in the distribution and bioaccessibility of $\mathrm{Ni}, \mathrm{V}$ and $\mathrm{Cr}$ in soils across Northern Ireland. Critically, such findings have applications beyond the study area as the diverse geology encountered in Northern Ireland extends stratigraphically beyond the immediate region.

\subsection{Methodology}

\subsection{Study Area and Sample Selection}

Northern Ireland hosts a wide variety of rock types relative to its small land area of just over $13,800 \mathrm{~km}^{2}$ with most geologic time periods represented by the study area's diverse lithology (Fig. 1; Wilson, 1972; Jordan et al., 2007). Bioaccessibility research in this study area therefore provides the opportunity to increase the global understanding of the relationships between geochemistry and human health within both the scientific and regulatory communities.

The range of rock types represents three basement terranes: the Grampian, the Midland Valley, and the Southern Uplands-Down-Longford Terranes. As described in Mitchell (2004), the Grampian Terrane and associated rocks in the northwest represent the oldest rocks in the country, with their metamorphic igneous and sedimentary origins spanning the Proterozoic Era. Psammites and semi-pelites are the dominant rock type, with sandstone and conglomerate also present in this area. Following from the Proterozoic through to the Devonian, the Midland Valley Terrane hosts Palaeozoic igneous formations and Late Devonian-Early Carboniferous sedimentary rocks. Red sandstones, limestone and mudstones comprise the majority of rock types with a minor conglomerate component. Finally, granitic igneous intrusives and marine sedimentary rocks representing the Lower Palaeozoic Ordovician and Silurian 
systems are found in the Southern Uplands-Down-Longford Terrane in the southwest. Lithic arenites and sandstones comprise the majority of bedrock in this part of the country. Portions of the Midland Valley and Grampian basement rocks in the northeast are covered by a large plateau of igneous Palaeogene basalts and lava-derived sedimentary clays originating from within the Permian to Cretaceous systems to a depth of up to 800 meters. Outside of this area, much of the basement rocks in Northern Ireland remain exposed. In contrast to the diverse range of underlying rock types, superficial deposits are dominated by glacial till, sand and gravel, and peat, and topsoil $\mathrm{pH}$ falls within a relatively narrow acidic range.

Eleven generic bedrock types as defined by the Geological Survey of Northern Ireland (GSNI; Smyth, 2007) are illustrated in Fig. 1. Geochemical and bioaccessibility data were separated into these groups prior to EDA with the aim of identifying potential differences in soil geochemistry and trace element bioaccessibility across different underlying bedrock types. Using generic bedrock types ensures that sample sizes remain sufficiently robust during analysis and EDA, as defining discrete minor geologic formations present in Northern Ireland would reduce sample sizes to a prohibitively narrow range of statistical significance. Such an approach also reduces variance and increases normality in the distribution of geochemistry data (Jordan et al., 2007; Zhang et al., 2007; Palmer et al., 2013).

Geochemistry data from the Northern Ireland Tellus Survey were provided by the GSNI. In excess of 6800 shallow profile soil samples from $5-20 \mathrm{~cm}$ depth were gathered during the Tellus Survey and analysed by X-ray fluorescence spectrometry (XRFS) for major oxides and trace elements. The complete Tellus Survey field methods and analytical methodology are described in Smyth (2007). Shallow soil samples from the Northern Ireland Tellus Survey soil archive were used for bioaccessibility testing and were selected to represent the diversity of rock and soil types across the study area.

\subsection{Bioaccessibility Testing}

The UBM is an in vitro extraction procedure for solid matrices designed to mimic the conditions of the human digestive system. The method incorporates saliva, gastric, and intestinal phases of digestion at a controlled temperature of $37^{\circ} \mathrm{C}$. The full methodology is downloadable through the British Geological Survey (BGS) website (BARGE/INERIS, 2011).

Soil sub-sampling, solution preparation, UBM extractions and inductively coupled plasma mass spectrometry (ICP-MS) analyses were conducted in the Analytical Geochemistry Facility at BGS, Kingsley Dunham Centre, Keyworth, Nottingham during 2009 (Barsby et al., 2012) and 2013. Archived Northern Ireland Tellus soils from the $<2 \mathrm{~mm}$ fraction were sub-sampled by coning and 
quartering to ensure representative samples were obtained prior to extraction. The 2009 and 2013 bioaccessibility data sets were joined to ensure the diverse range of rock types present within the study area was adequately represented.

Fresh digestion fluids were prepared daily and one day prior to use to allow enzymes and $\mathrm{pH}$ to stabilise. Inorganic and organic solutions for each fluid were prepared in separate $500 \mathrm{ml}$ glass volumetric flasks prior to combining in two litre non-reactive screw top Nalgene bottles to create one litre of digestive fluid. Additional solid reagents were weighed directly into the Nalgene bottles prior to adding the inorganic and organic solutions. Digestive fluids were immersed in the same warm water bath used for the extractions at $37^{\circ} \mathrm{C}$ for a least one hour prior to commencing extractions. The $\mathrm{pH}$ of each solution was checked and adjusted to the specifications outlined in Table 1 using either $37 \% \mathrm{HCl}$ or $1 \mathrm{M} \mathrm{NaOH}$.

\subsubsection{Extract Analysis and Quality Control}

The UBM has been validated for As, $\mathrm{Pb}$ and Cd through in vivo studies (Caboche, 2009; Denys et al., 2012). It should be noted that, whilst the three trace elements presented in this paper have not been subjected to in vivo validation under the UBM, data for all trace elements of interest were subjected to rigorous quality control $(\mathrm{QC})$ and quality assurance $(\mathrm{QA})$ procedures as described below.

Extract analysis was carried out using an Agilent 7500cx series ICP-MS employing an octopole reaction system in combination with a CETAC autosampler. Sample introduction from the autosampler to the ICP is coupled to a CETAC flow injection valve. The instrument was calibrated at the beginning of every analytical run using a minimum of three standards and a blank for each trace element. Multielement QC check standards containing the trace elements of interest at $25 \mu \mathrm{g} / \mathrm{L}$ were analysed at the start and end of each run and after a minimum of every 25 samples.

Accuracy and precision of UMB extract analysis is monitored at BGS by the on-going collation of BGS102 reference material data (Wragg, 2009). UBM results from ICP analysis were provided in $\mu \mathrm{g} / \mathrm{L}$ with a dilution factor of 100 applied. Data were back calculated to $\mathrm{mg} \mathrm{kg}^{-1}$ of soil using Equation A, taking into account recorded soil sub-sample weights and total fluid volumes inclusive of $\mathrm{HCl}$ or $\mathrm{NaOH}$ additions used for $\mathrm{pH}$ adjustments.

$$
C[m g / k g]=\left\{C[\mu g / L] \times \frac{V}{W}\right\} \div 1000
$$


where $C=$ analyte concentration in units specified, $V=$ total extraction fluid volume $(\mathrm{mL})$ and $W=$ total soil weight (g). Soils were pre-dried according to the Tellus methodology (Smyth, 2007); 100\% solids were therefore assumed for calculating final concentrations.

For every seven unknown soil samples, one extraction blank, one duplicate soil and one BGS102 certified reference soil were included in the extraction procedure. Measured values for bioaccessible As and $\mathrm{Pb}$ were within one standard deviation of the certified reference value provided for BGS102. Overall mean gastric relative per cent difference for the analytes of interest was $11 \%$. Values measured in blanks above daily detection limits were subtracted from measured sample values for each respective batch. Measured sample values below daily detection limits were reported as half the daily detection limit.

\subsection{Geochemistry and UBM Data Analysis}

Analysis of geochemistry and trace element bioaccessibility data relied upon a combined approach where intrinsic statistical relationships among variables were eyaluated in the context of corresponding spatial outputs. Multivariate dimension reduction in the form of PCA was applied to link variables to a narrower range of soil-geochemical components such as specific soil or bedrock types. Conclusions were subsequently drawn about specific soil-geochemical influences causing variability in the geographical distribution and bioaccessibility of $\mathrm{Ni}, \mathrm{V}$ and $\mathrm{Cr}$.

Summary statistics were generated for XRFS geochemistry data in Microsoft (MS) Excel 2010 and IBM SPSS v.19.0. Boxplot figures were completed in R (R Core Team, 2013). PCA was conducted in R using the vegan package (Oksanen et al., 2013) and eigenvalue loading plots with eigenvectors were manually constructed using PCA eigenvalue factor loadings. Geochemistry variables, synonymous with factors for the purposes of PCA, were selected on the basis of their known potential to influence trace element bioaccessibility (Stewart et al., 2003; Subacz et al., 2007; Poggio et al., 2009; Meunier et al. 2010; Bradham et al., 2011) and consisted of eight major element oxides (\%), pH, loss on ignition (\%; LOI), and total $\mathrm{Ni}, \mathrm{V}$, and $\mathrm{Cr}\left(\mathrm{mg} \mathrm{kg}^{-1}\right)$.

To address issues of data closure encountered in compositional geochemical data, an additive log ratio transformation was applied to the data set using the robComposition package in R (Templ et al., 2009). Titanium dioxide was chosen as the rationing variable for transformation (Reimann et al., 2009). Values for the thirteen geochemistry factors noted above from 6,862 sample locations were analysed by PCA using scaled Northern Ireland Tellus XRFS data for shallow soils. Scaling data corrects for variability in the magnitude of values that will naturally be present in a data set with multiple factors (Oksanen et al., 2013). To explore relationships between trace element bioaccessibility and Northern 
Ireland geochemistry, UBM data inclusive of XRFS data from corresponding study set soil sample locations were also analysed by PCA following the same methods described above.

PCA is an unconstrained ordination method that is useful for dimension reduction in multivariate data. Data are transposed onto a three dimensional axis where the Euclidian distance between points is calculated in each direction. Similar to a one-dimensional linear regression, a line of best fit is calculated accounting for maximum variance between the data points; this vector is the first principal component (PC1). The second principal component (PC2) is the vector which lies perpendicular to PC1. Data are rotated in three dimensional space to repeat this process and derive subsequent components. Eigenvalues represent the proportion of factor variance accounted for by a particular component, providing the same level of information as an $r^{2}$ value in linear regression. In addition to factor eigenvalues, each soil sample location is assigned a unique site score. Site scores give an indication of individual data positions and resulting relative weightings along component vectors in three dimensional space. A higher score indicates more sample variance is accounted for by a prescribed component (Reimann et al., 2009; ESRI, 2010; Oksanen et al., 2013).

Geochemistry variables and PCA site scores were mapped in ArcMap v.10 using ordinary kriging. Semi-variograms were manually fitted to geochemistry data using an iterative process of varying search neighbourhoods until the model yielding the least mean prediction error and best fit semi-variogram was generated. Spatial PCA applies identical ordination methods as described previously, but additionally generates raster outputs of unique site scores against each principal component to facilitate interpolation of a site score surface. Final interpolated outputs show sample location variance accounted for by the specified principal component (ESRI, 2010; Candeias et al., 2011).

\subsection{Results}

\subsection{Regional Trends in Geochemistry}

Table 2 provides summary statistics for oxides, trace elements, $\mathrm{pH}$ and LOI. $\mathrm{Ni}, \mathrm{Cr}$ and $\mathrm{V}$ concentrations are highest in soils overlying basalt bedrock types with their distributions controlled by a long-range $(a>70 \mathrm{~km})$ spatial function aligning with the extent of basalts in the northeast of the study area (Figs. 2 and 3, Table 3). Ni and $\mathrm{Cr}$ exhibit low concentrations in soils overlying the 10 other bedrock types investigated compared to $\mathrm{V}$, which displays more variability in its distribution across the study area (Figs. 2 and $3 b$ ). In particular, soils overlying sandstone and psammite \& semi-pelite bedrock types exhibit high concentrations of $\mathrm{V}$.

Magnesium ( $\mathrm{Mg}$ ), calcium (Ca), manganese $(\mathrm{Mn})$ and iron $(\mathrm{Fe})$ oxides show high relative concentrations in soils overlying basalt rock types (Figs. 4-6). $\mathrm{Mg}, \mathrm{Ca}$ and $\mathrm{Fe}$ are present in the 
minerals olivine, plagioclase feldspar and augite, which together account for approximately $90 \%$ of the minerals in underlying basalt bedrock (Hill et al., 2001). Mn is also known to be elevated in basalts as it readily substitutes for $\mathrm{Fe}$ in olivine (Wedepohl, 1978). Aluminium oxide $\left(\mathrm{Al}_{2} \mathrm{O}_{3}\right)$ concentrations also appear to be controlled by underlying basalt, although Al distributions are not as strongly constrained by this bedrock type (Fig. $6 b$ ). 


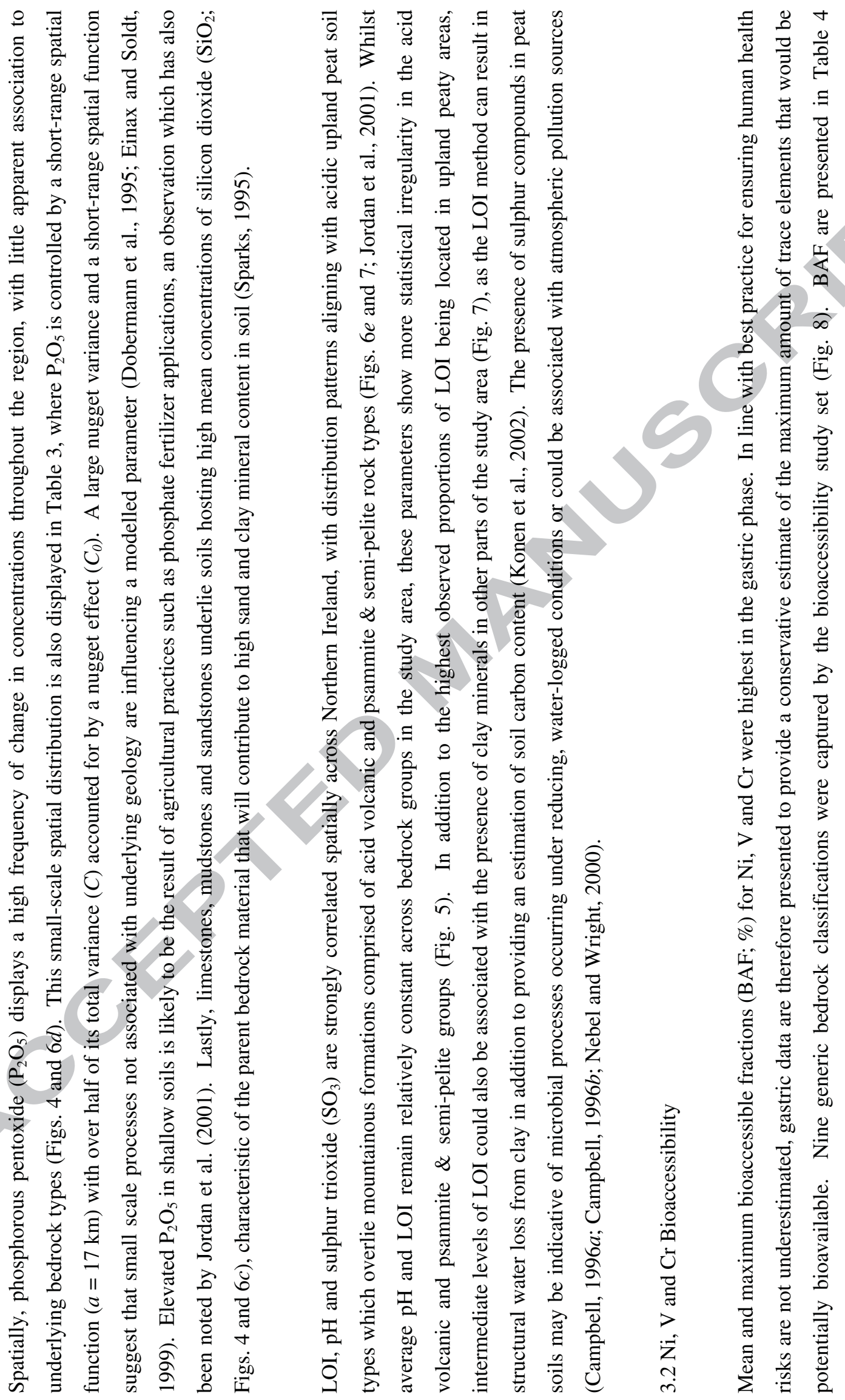




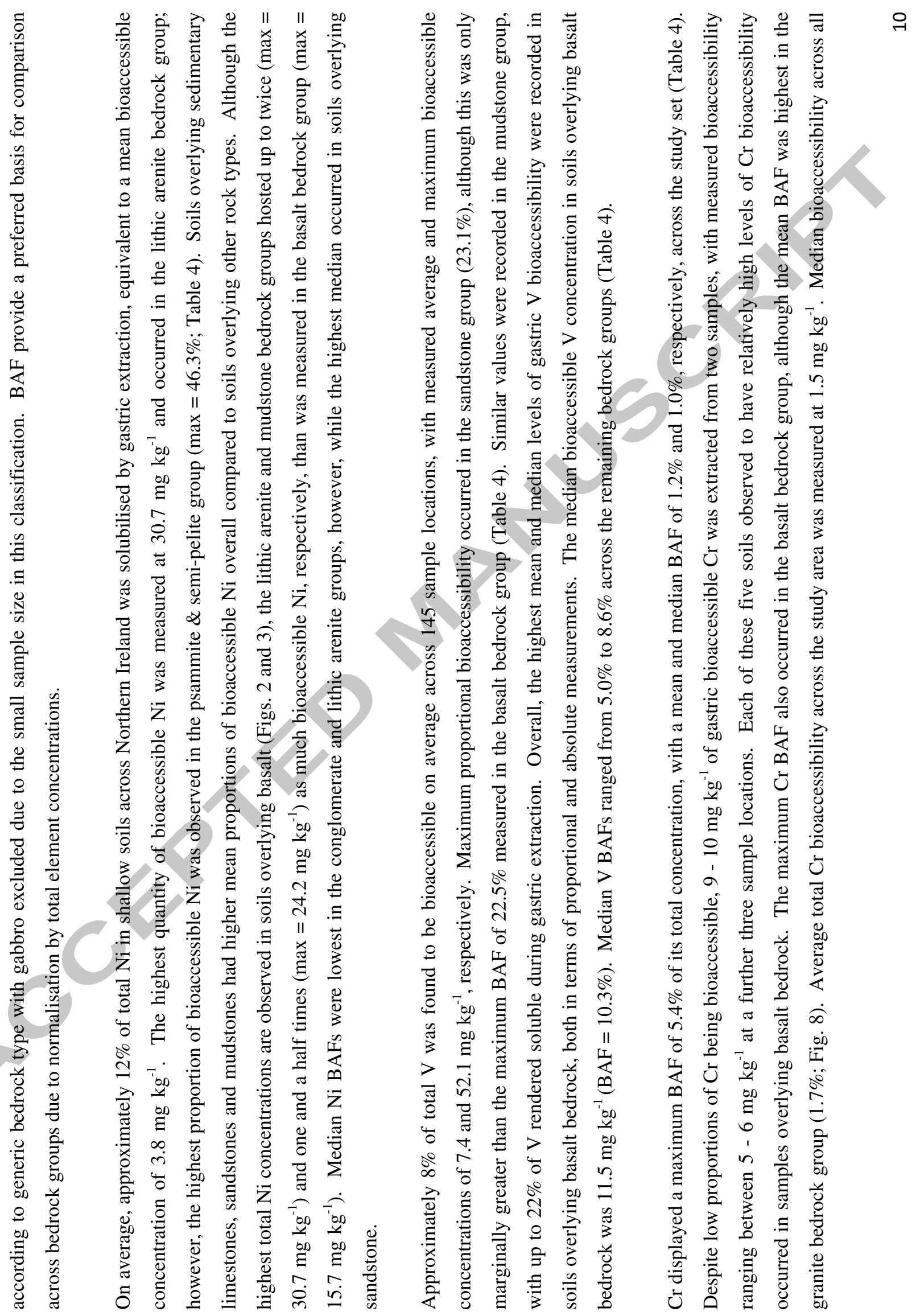




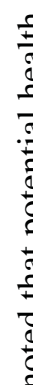

$\frac{8}{2}$

离 $\dot{\widehat{\sigma}}$

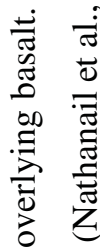

咅 总

$\exists \stackrel{0}{\Xi}$

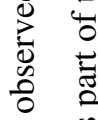

这

:

范

.50

$\stackrel{0}{ \pm}$

爱

๘े

范

过

I.

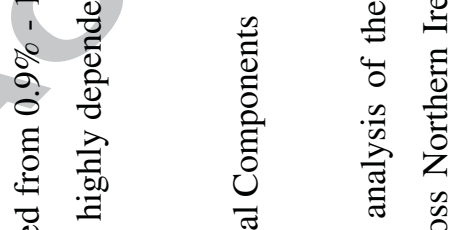

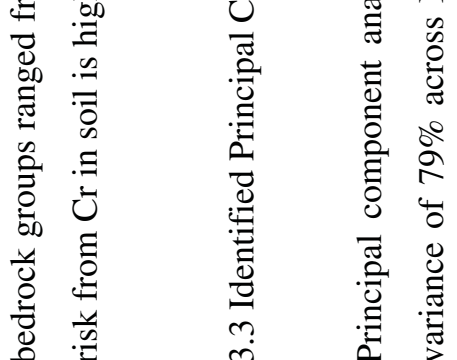

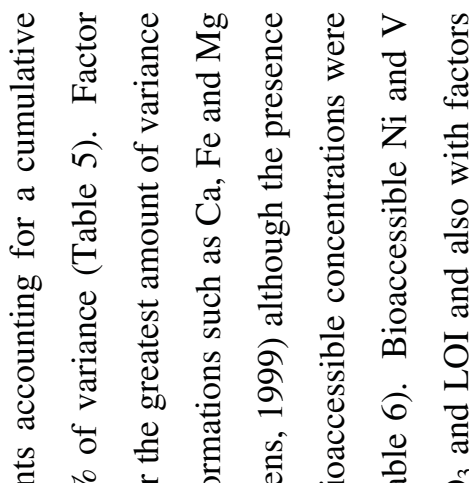

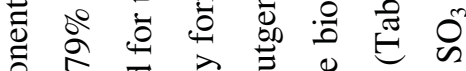

苛

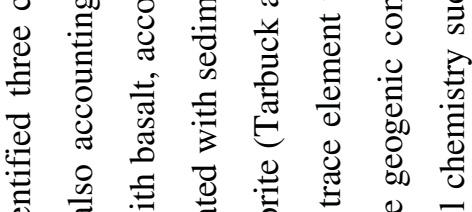

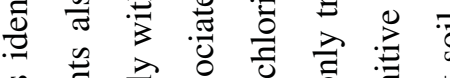

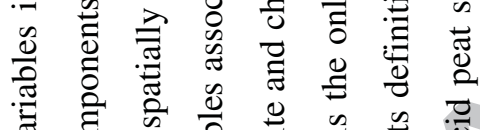

$\checkmark$ D

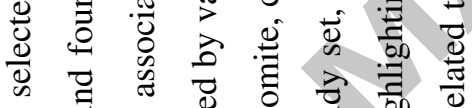

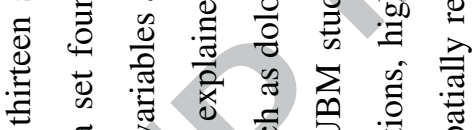

专

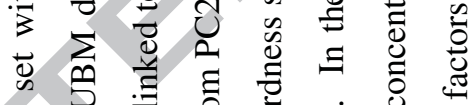

)

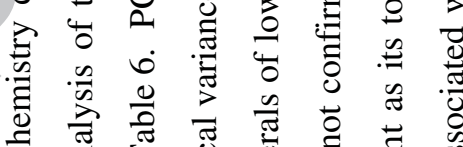

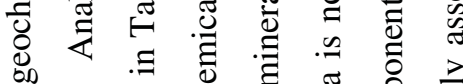

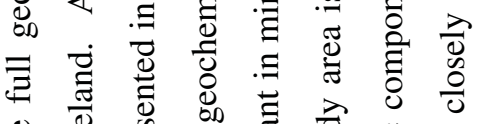

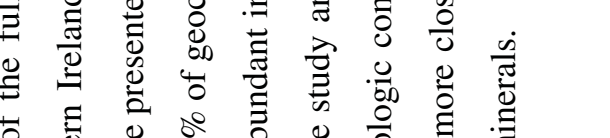

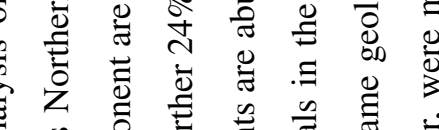

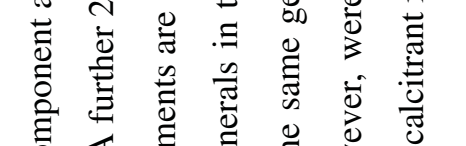

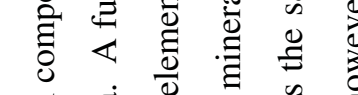

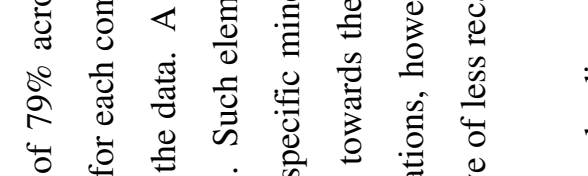

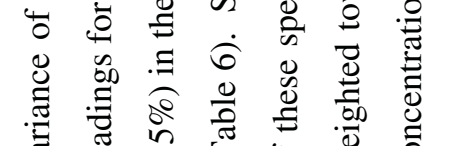

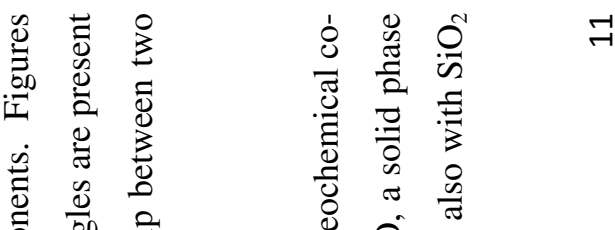

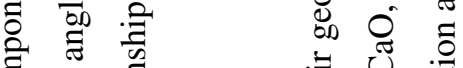

离 专

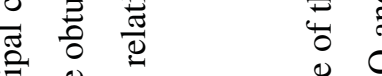

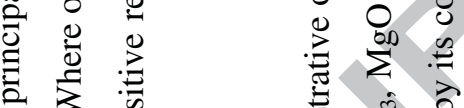

के

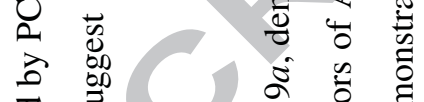

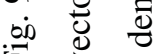

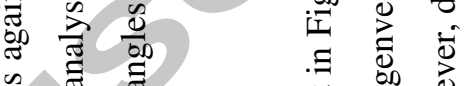

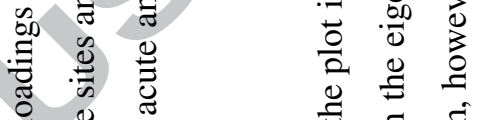

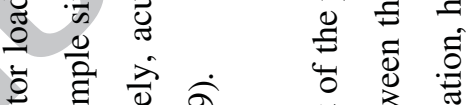

总离

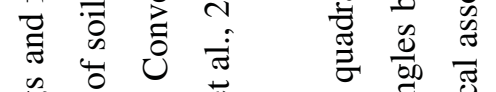

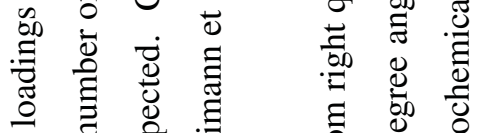

○ 完

.5

苛

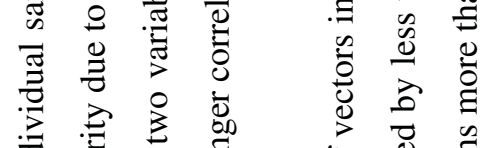

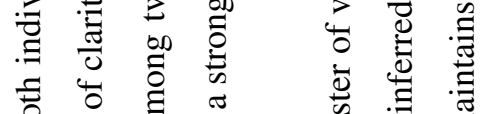

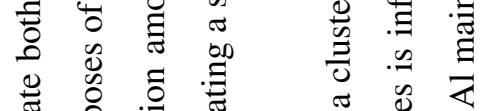

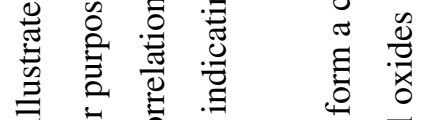

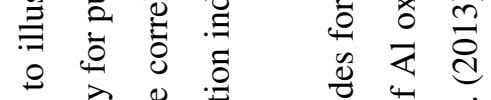

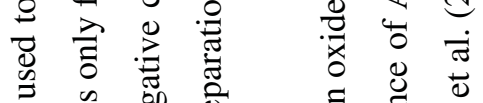

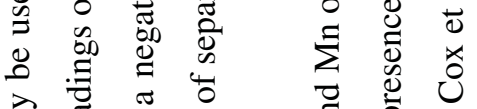

胥

苛

D.

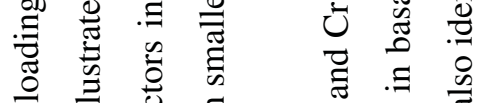

๑

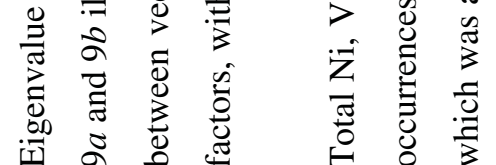




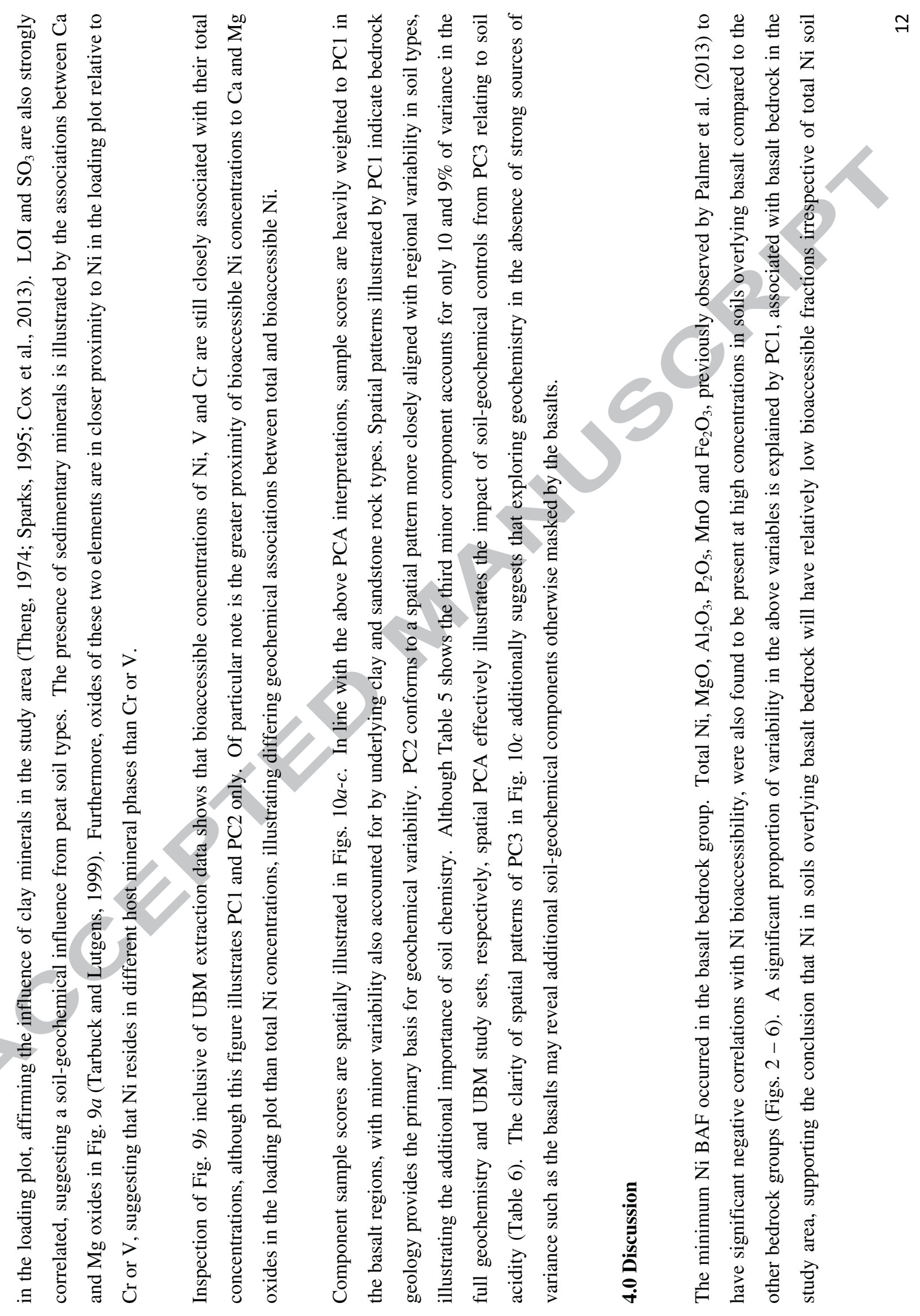




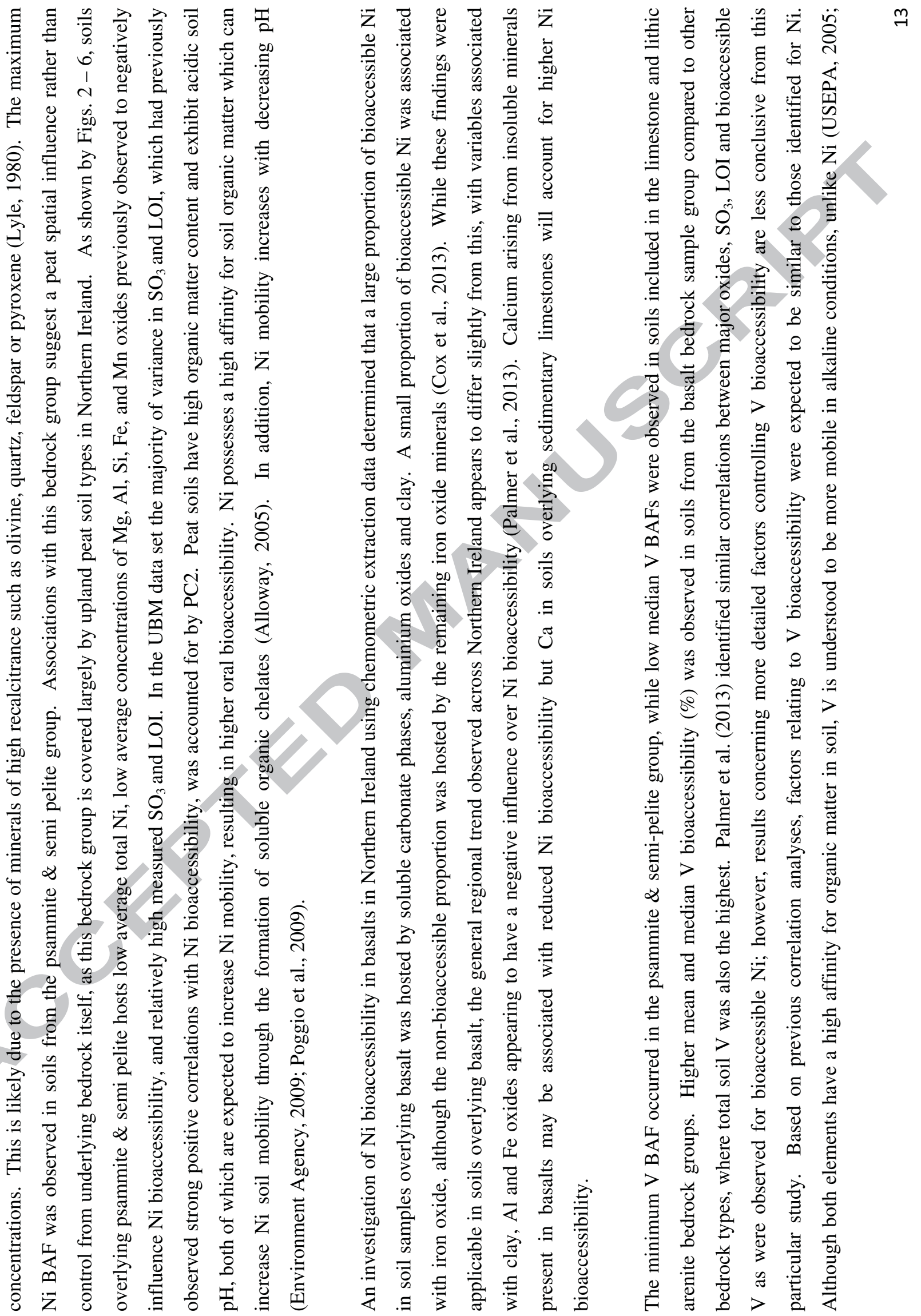




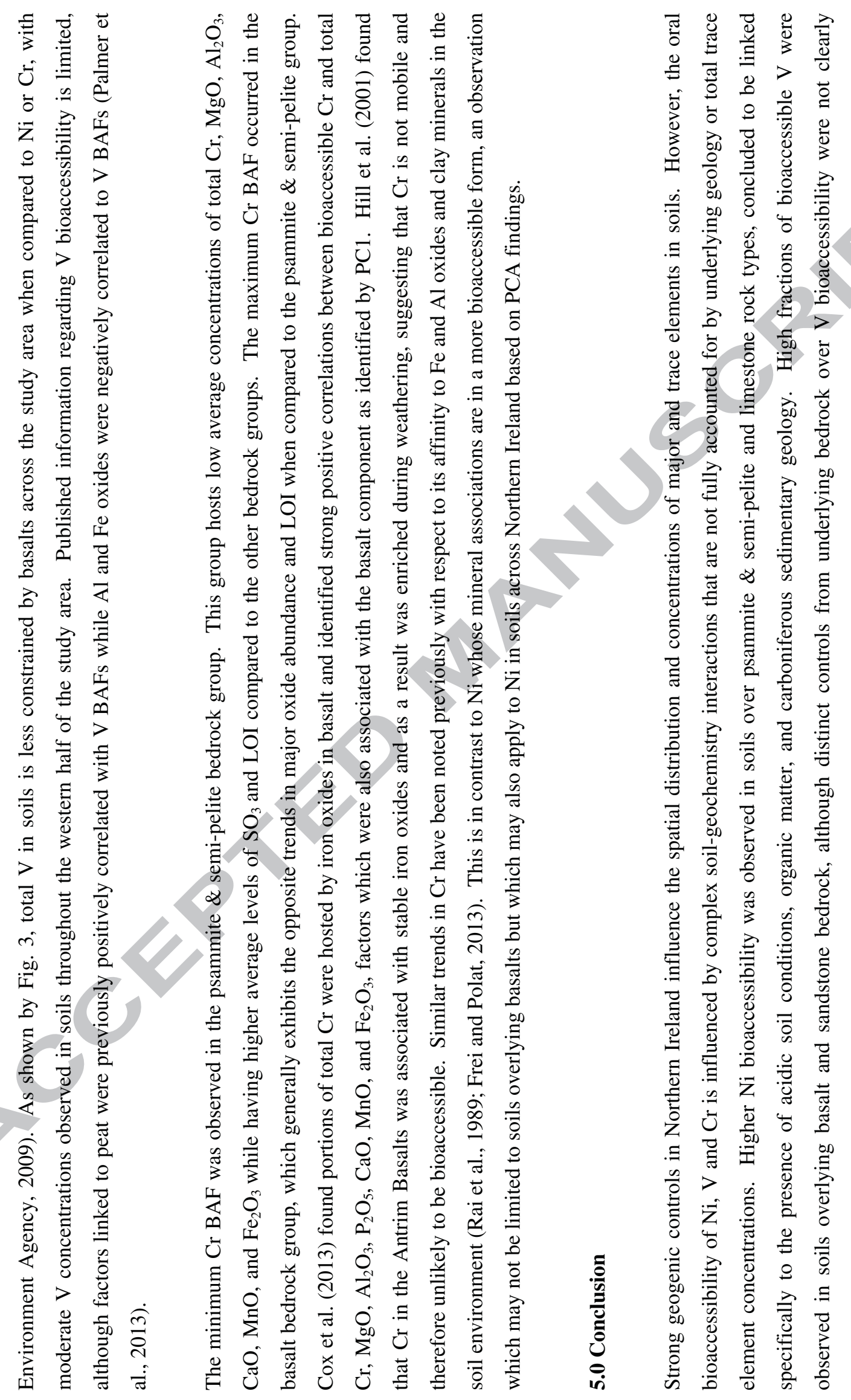




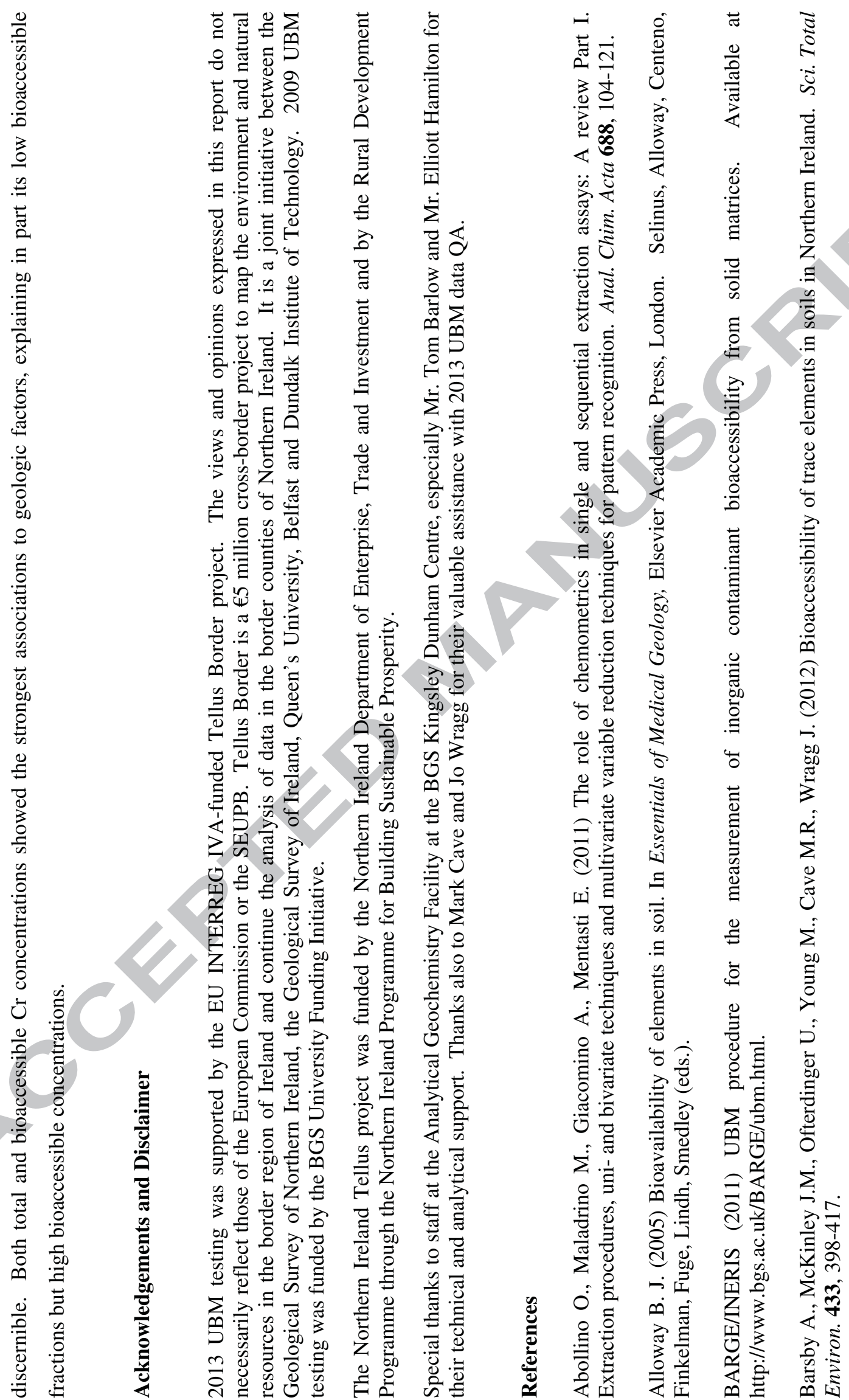




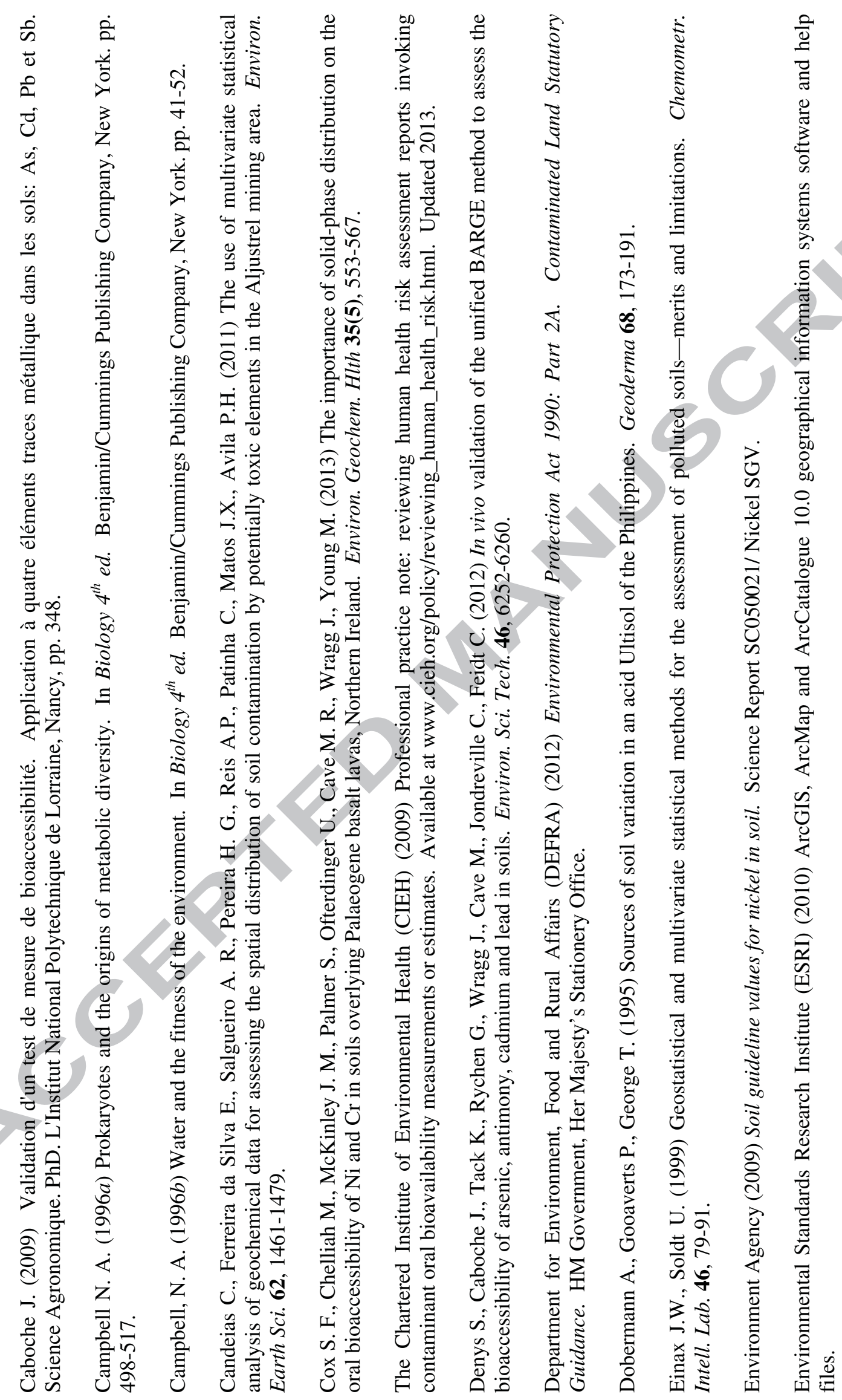




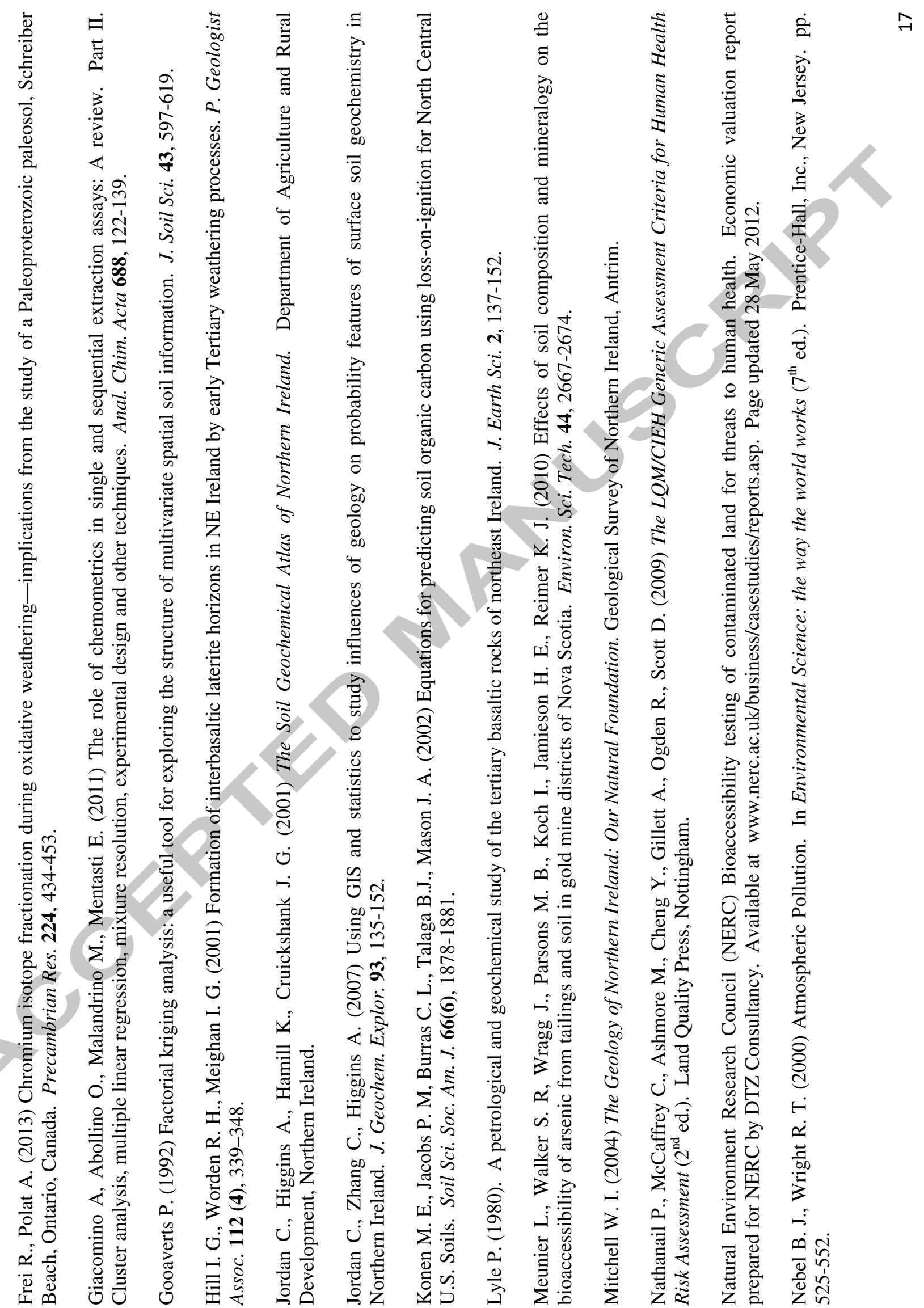




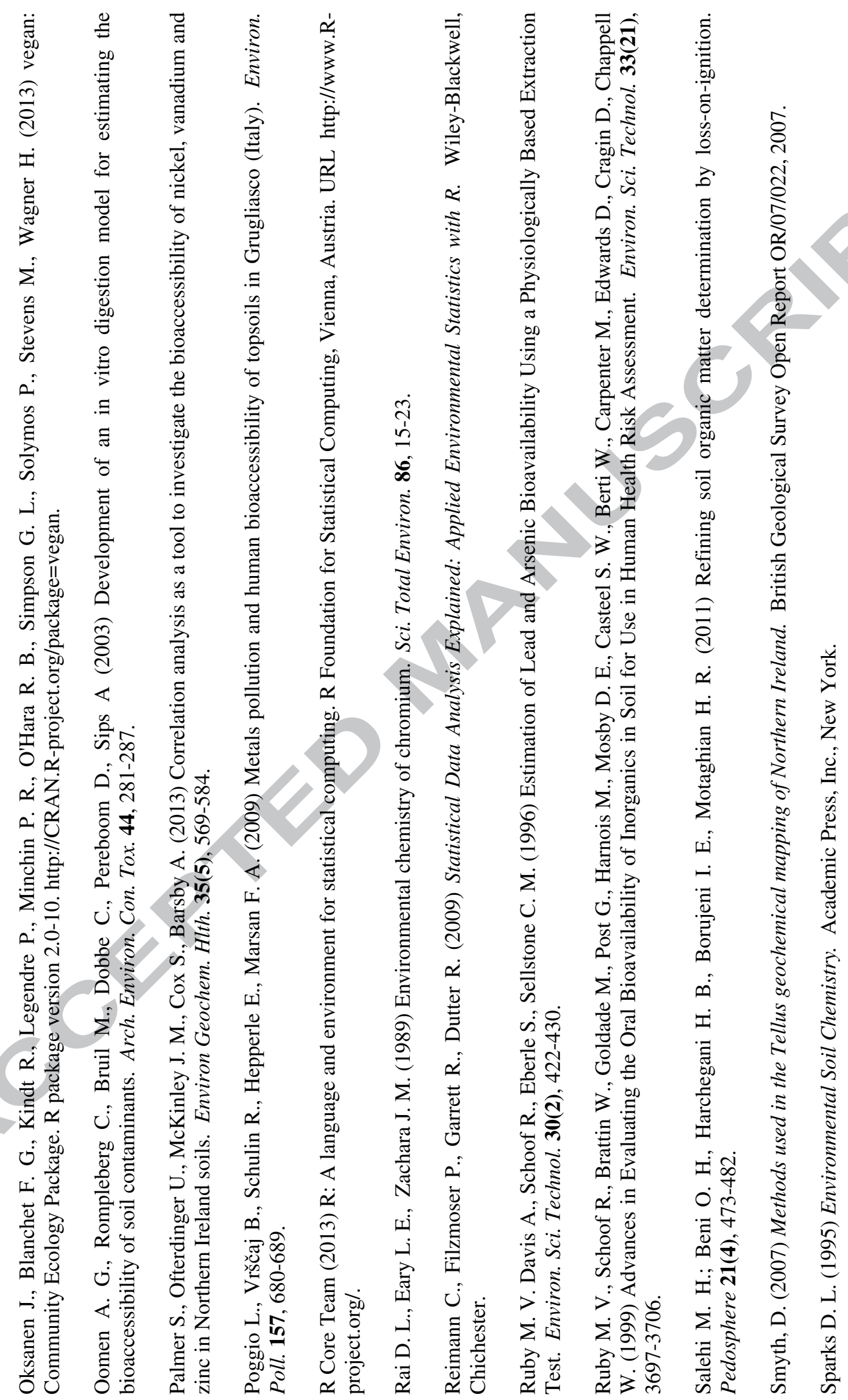




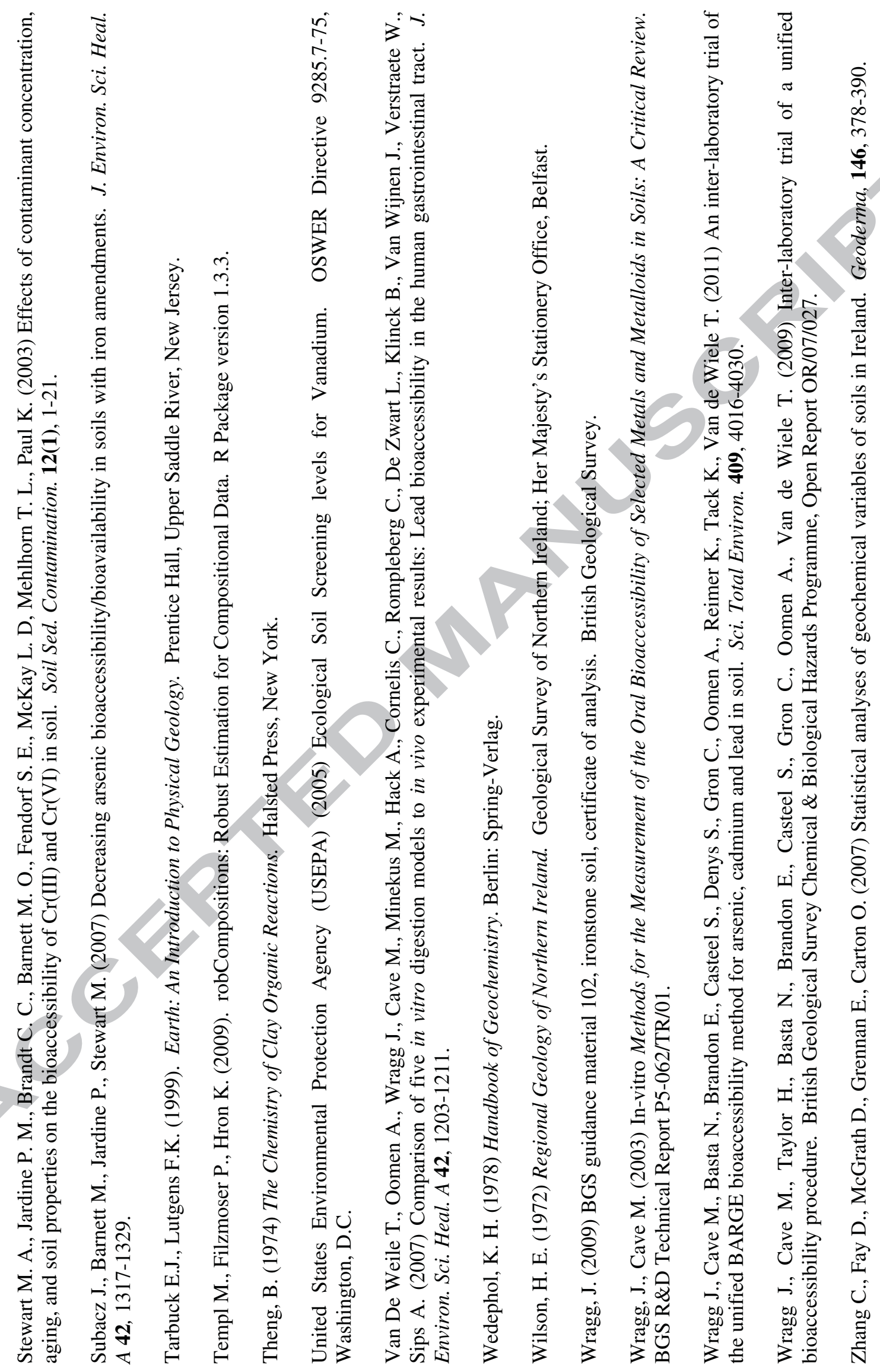




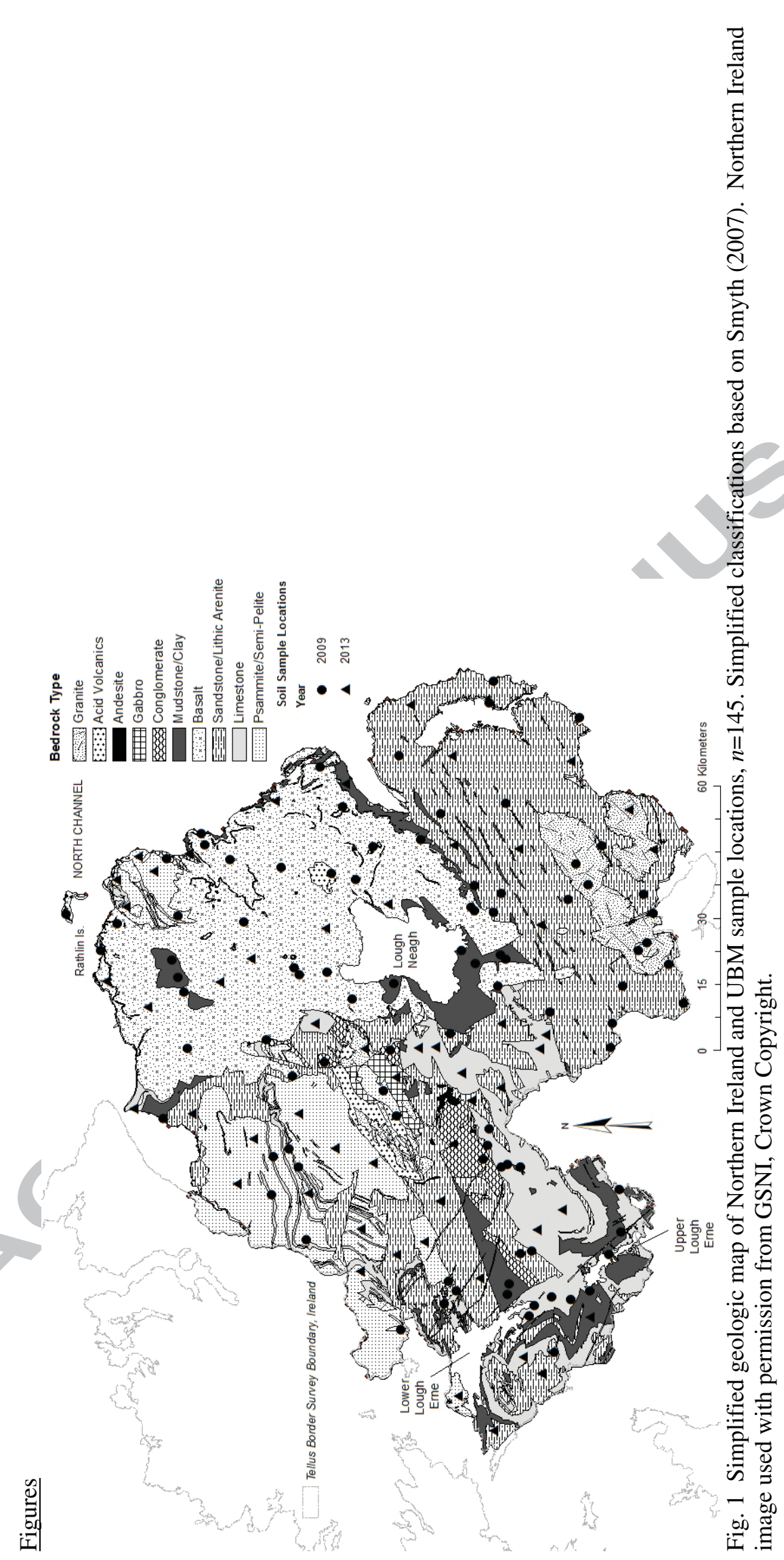




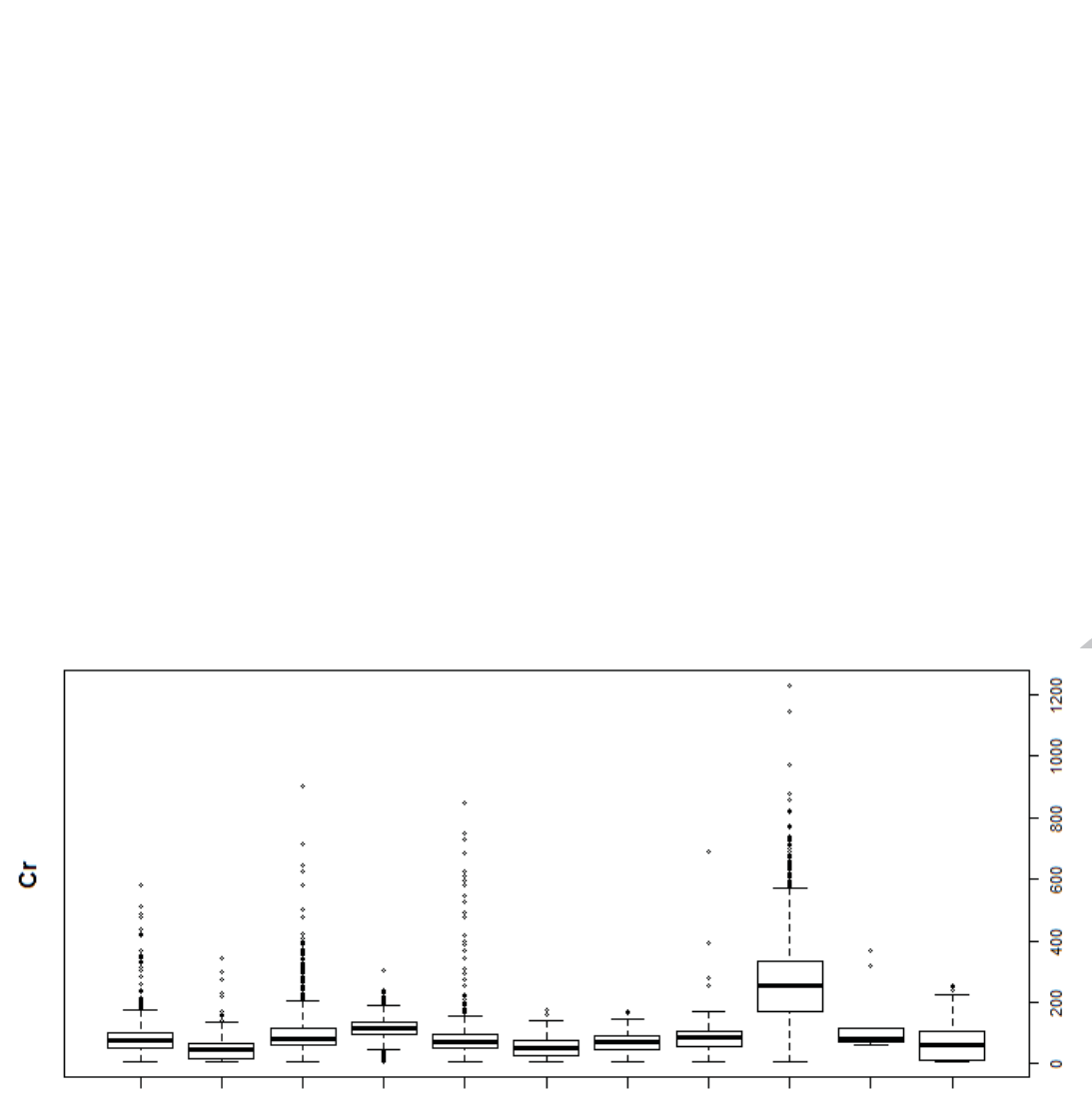

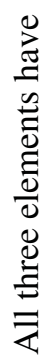

ก
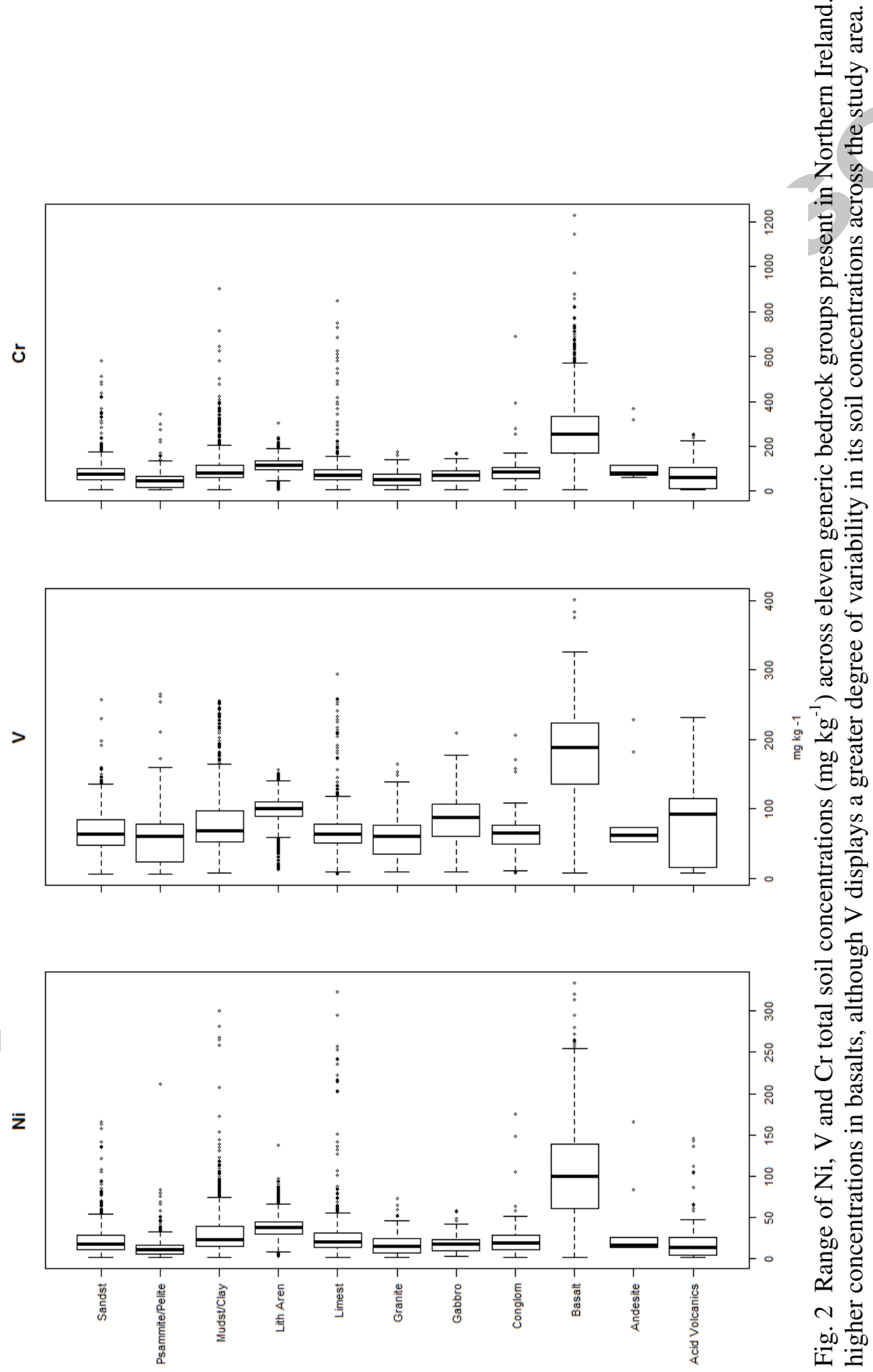

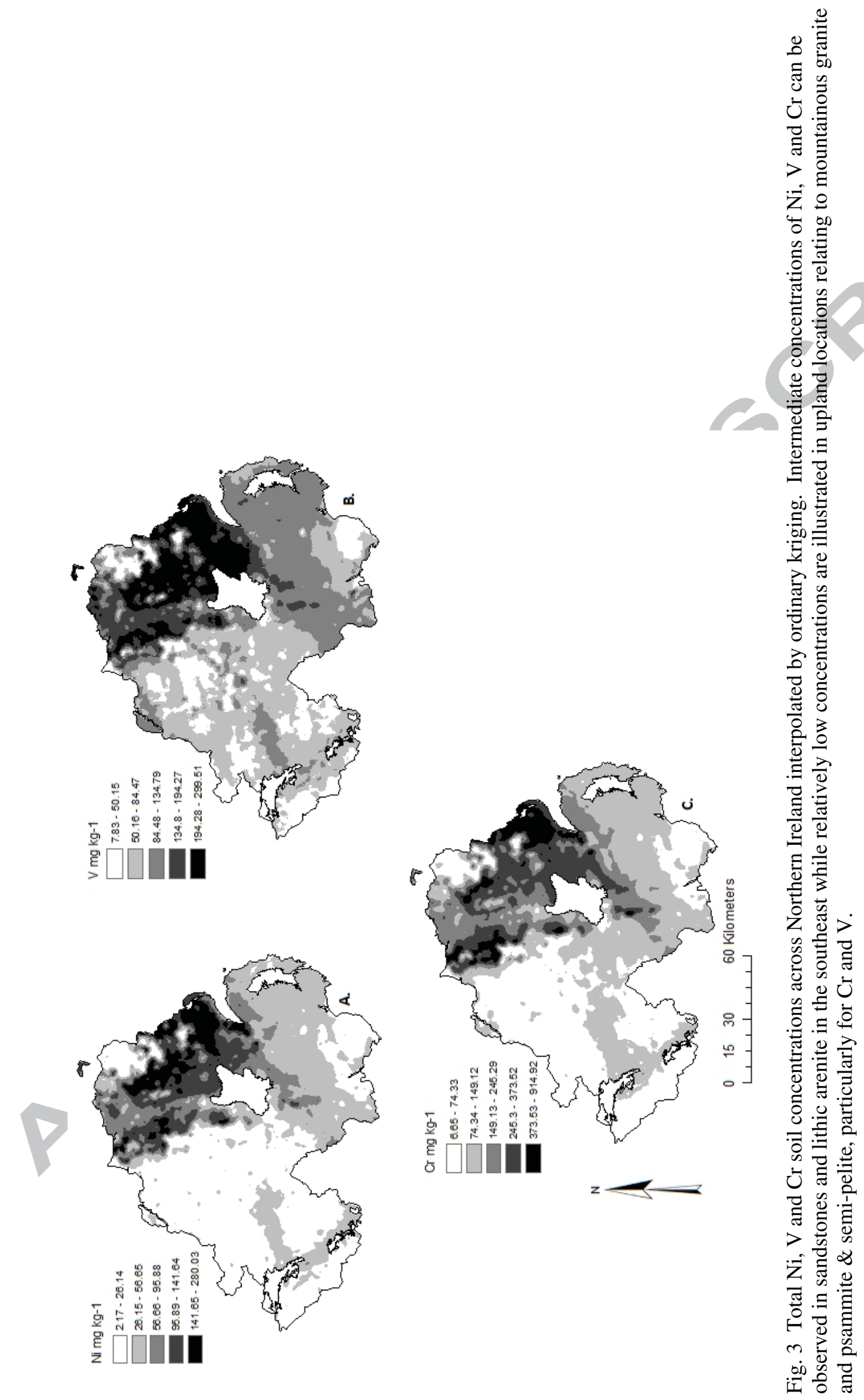

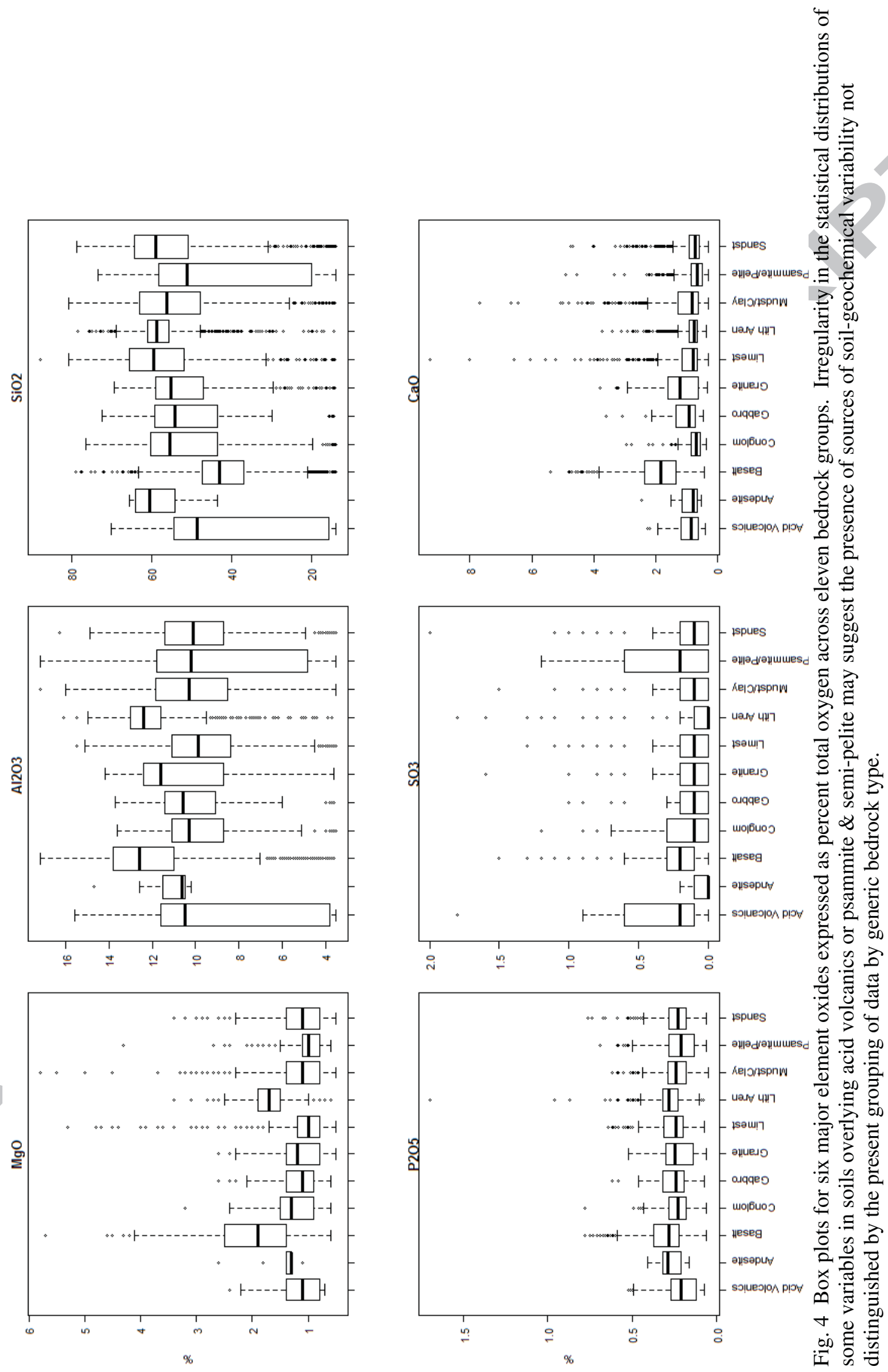

$\stackrel{d}{2}$
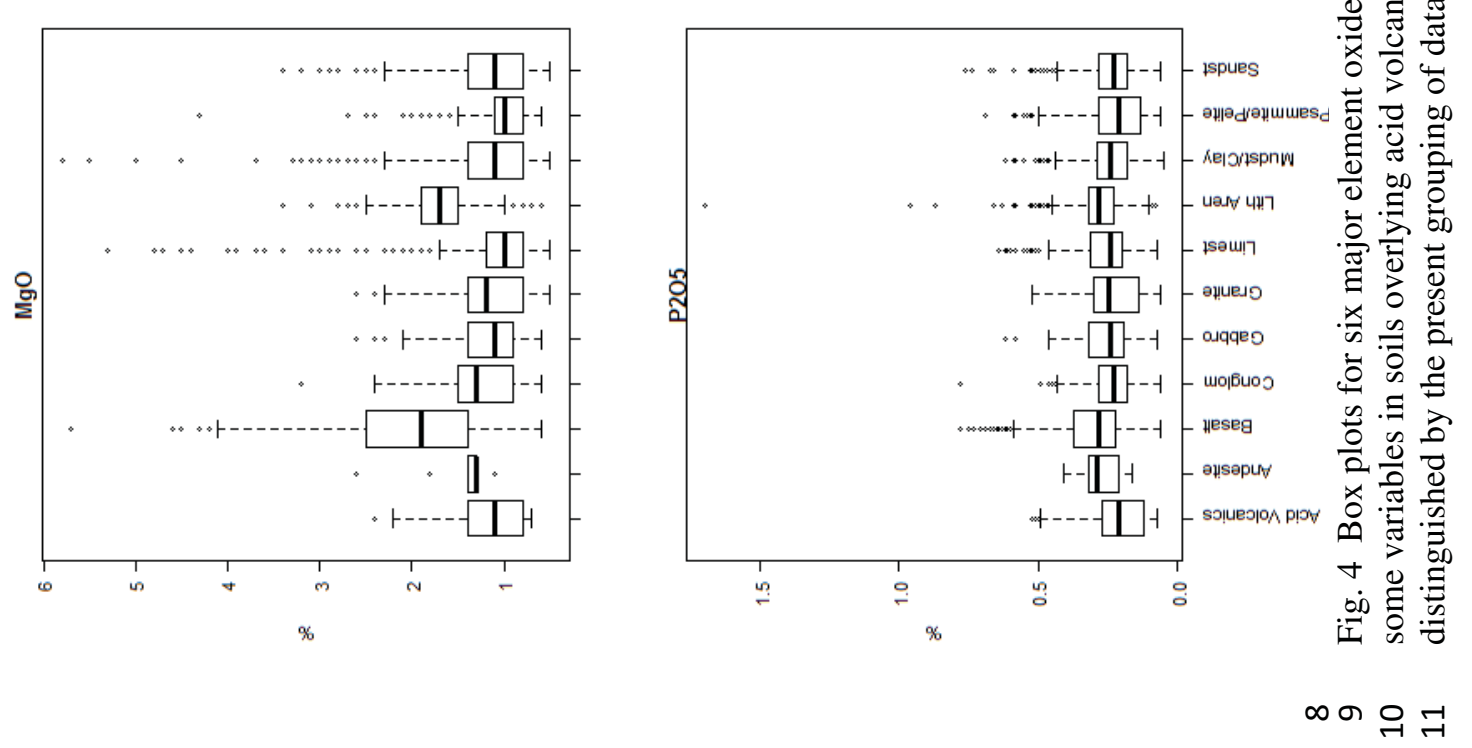

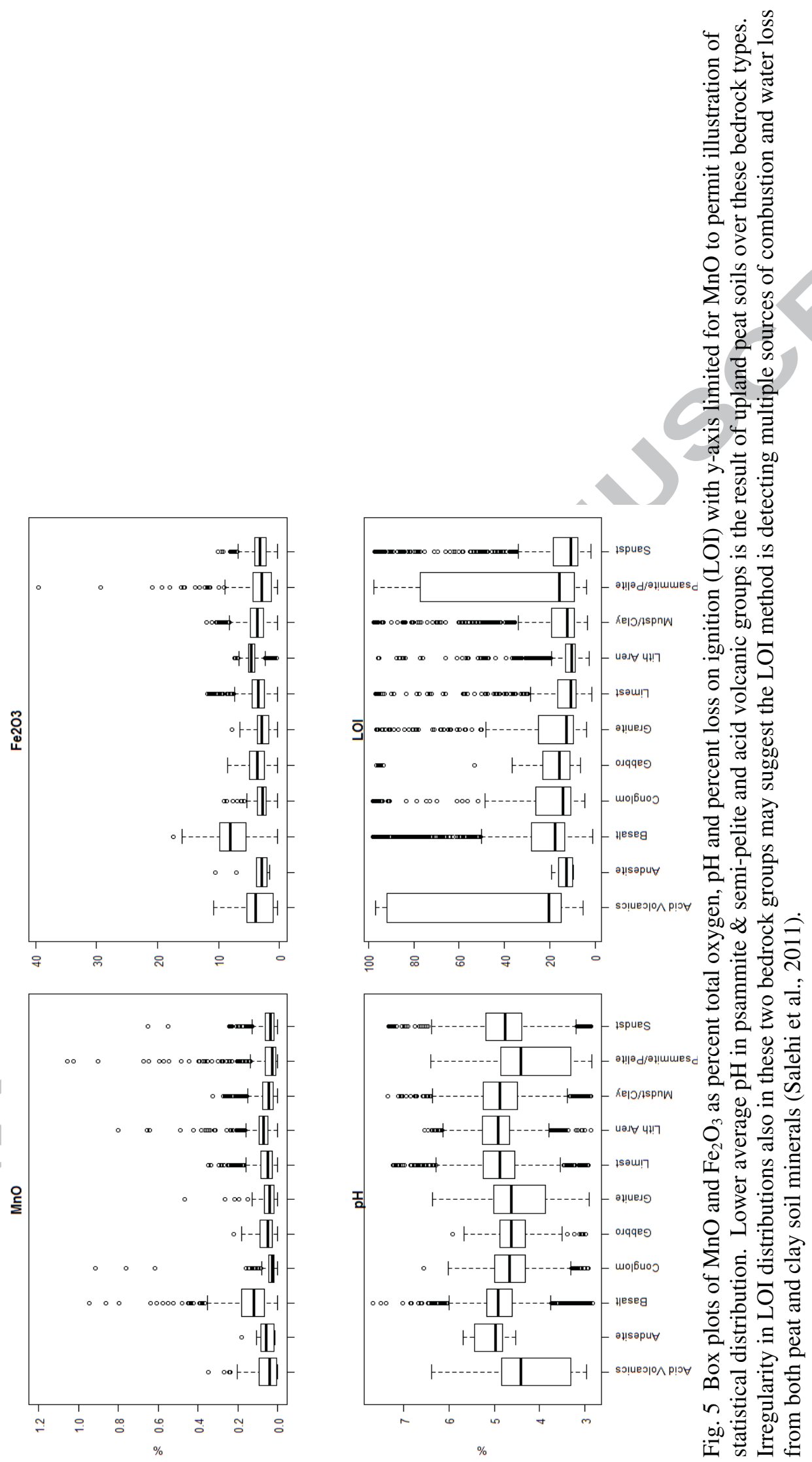
MgO \%

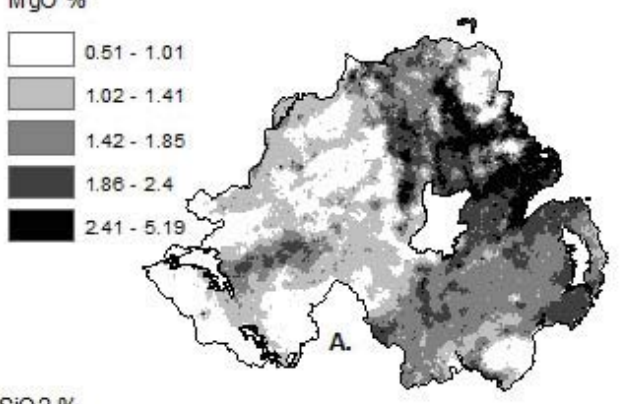

${ }_{3026}$

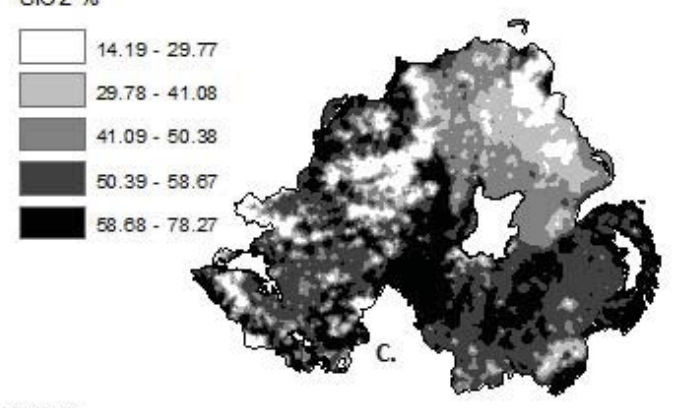

sons
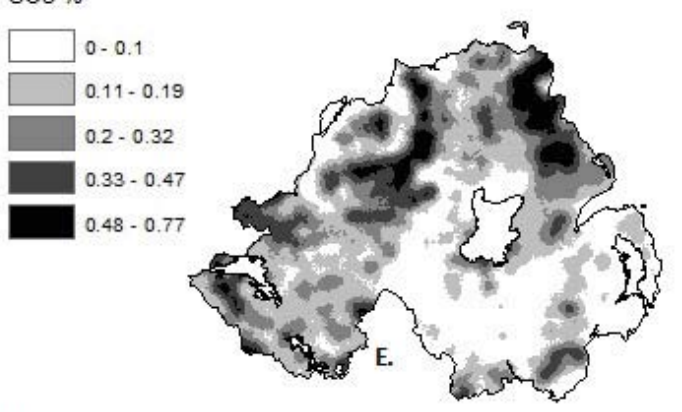

$\mathrm{MnO} \%$

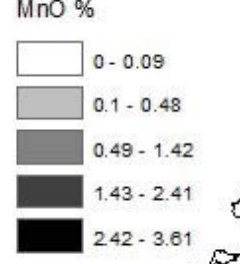

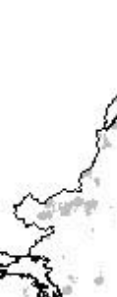

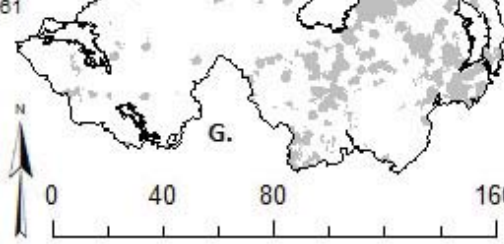

Al2O3\%

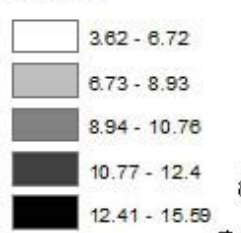

$\mathrm{P} 205 \%$
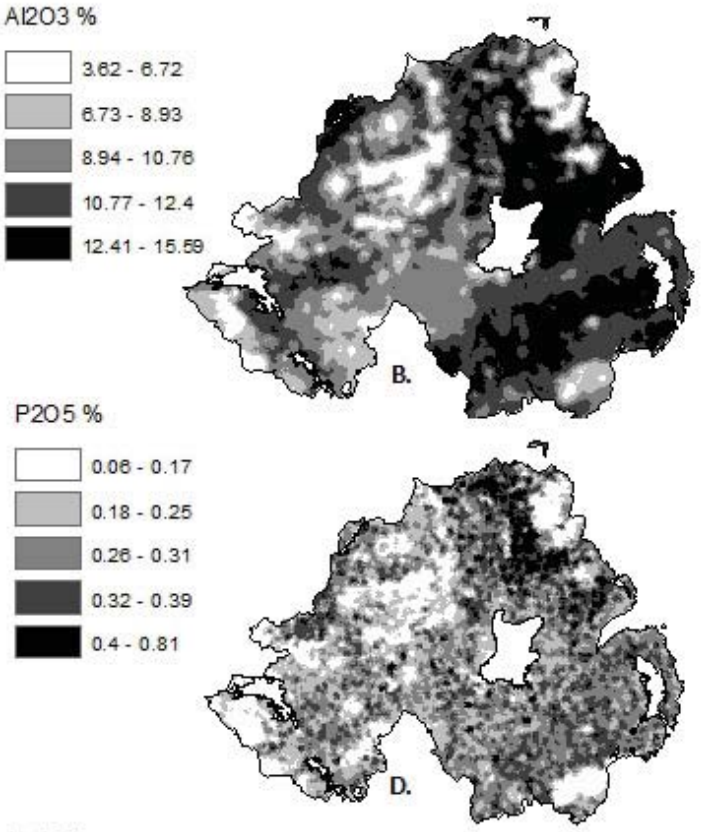

$\mathrm{CaO} \%$
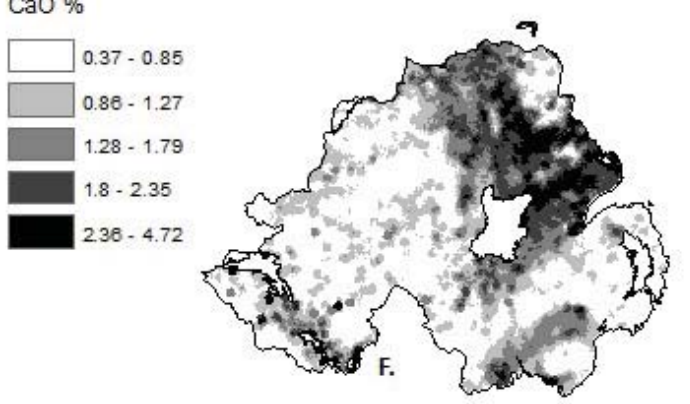

F⿻2035
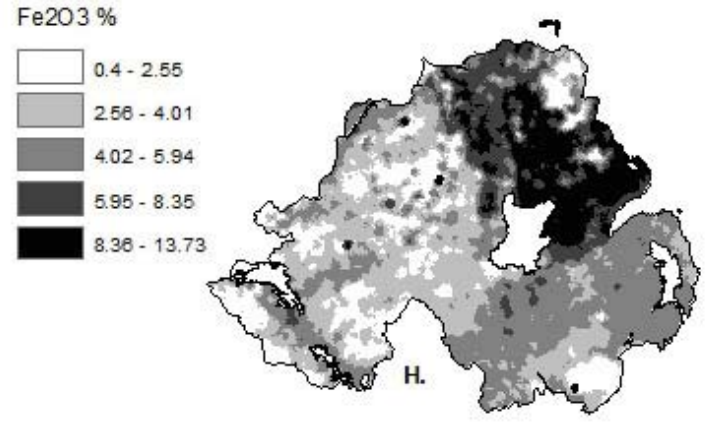

Fig. 6 Kriged major oxide distributions across Northern Ireland. $\mathrm{MgO}, \mathrm{CaO}$, and $\mathrm{Fe}_{2} \mathrm{O}_{3}$ are distinctly controlled by basalts in the northeast and most oxides with the exception of $\mathrm{SO}_{3}$ display relative deficiency in mountainous upland peat soils. $\mathrm{Al}_{2} \mathrm{O}_{3}$ and $\mathrm{SiO}_{2}$ show high concentrations in sandstone, lithic arenite, mudstones and limestones, whilst $\mathrm{P}_{2} \mathrm{O}_{5}$ is the only oxide whose distribution shows little apparent relationship to underlying geology. 


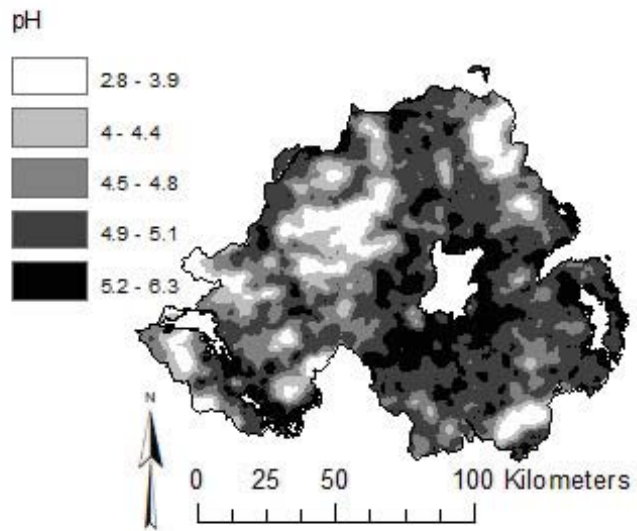

LOI \%

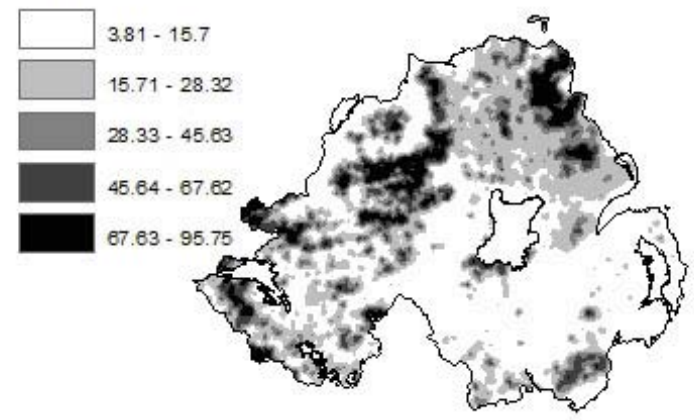

Fig. 7 Kriged soil $\mathrm{pH}$ and \% loss on ignition across Northern Ireland. LOI gives an approximation of soil carbon content as illustrated by high values corresponding with spatial patterns of upland peat distributions, also related to acidic soil $\mathrm{pH}$ conditions as shown left.
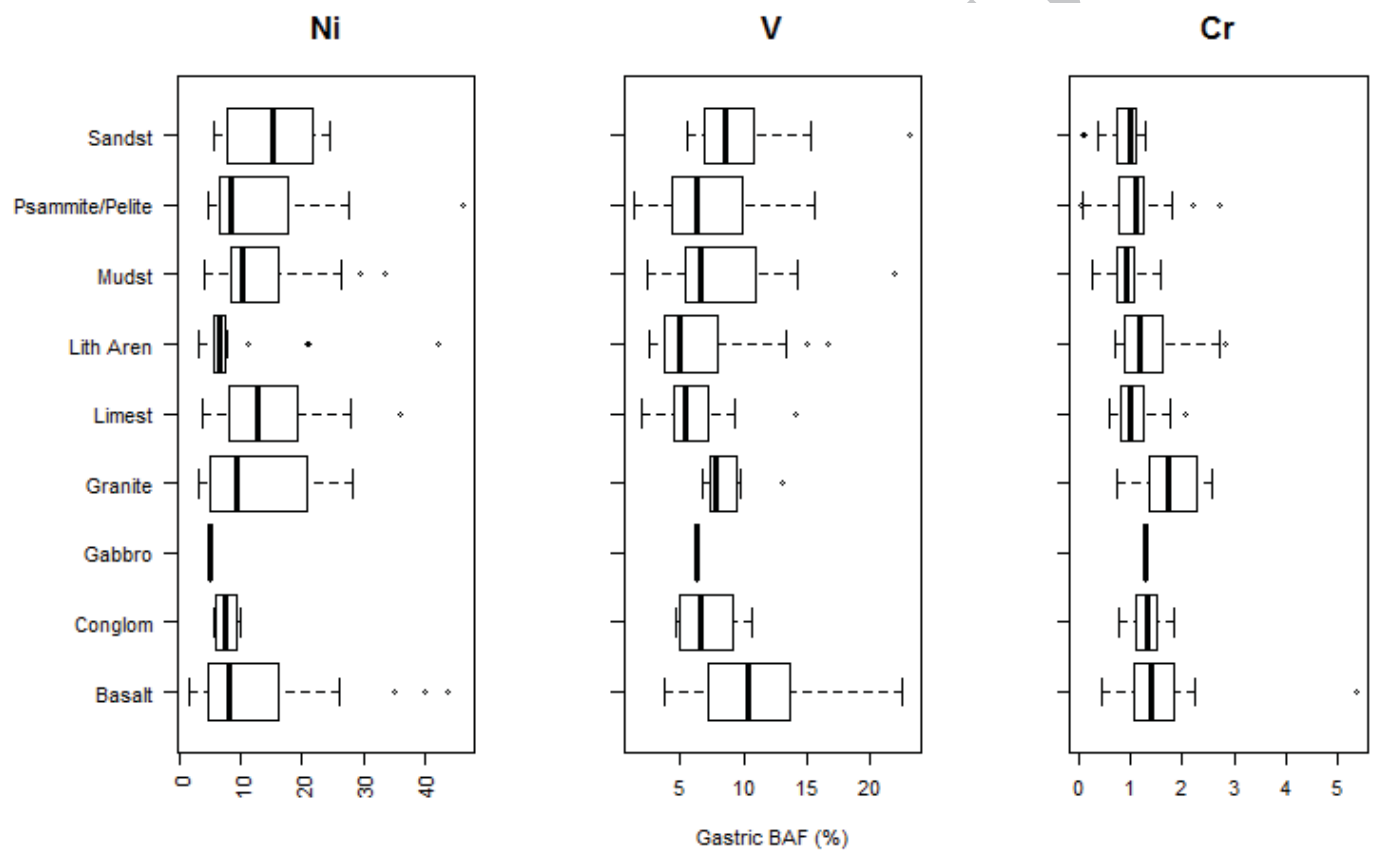

Fig 8. Boxplot distributions for gastric bioaccessible fractions of $\mathrm{Ni}, \mathrm{V}$ and $\mathrm{Cr}$ according to nine underlying bedrock groups captured by combined UBM study set. 

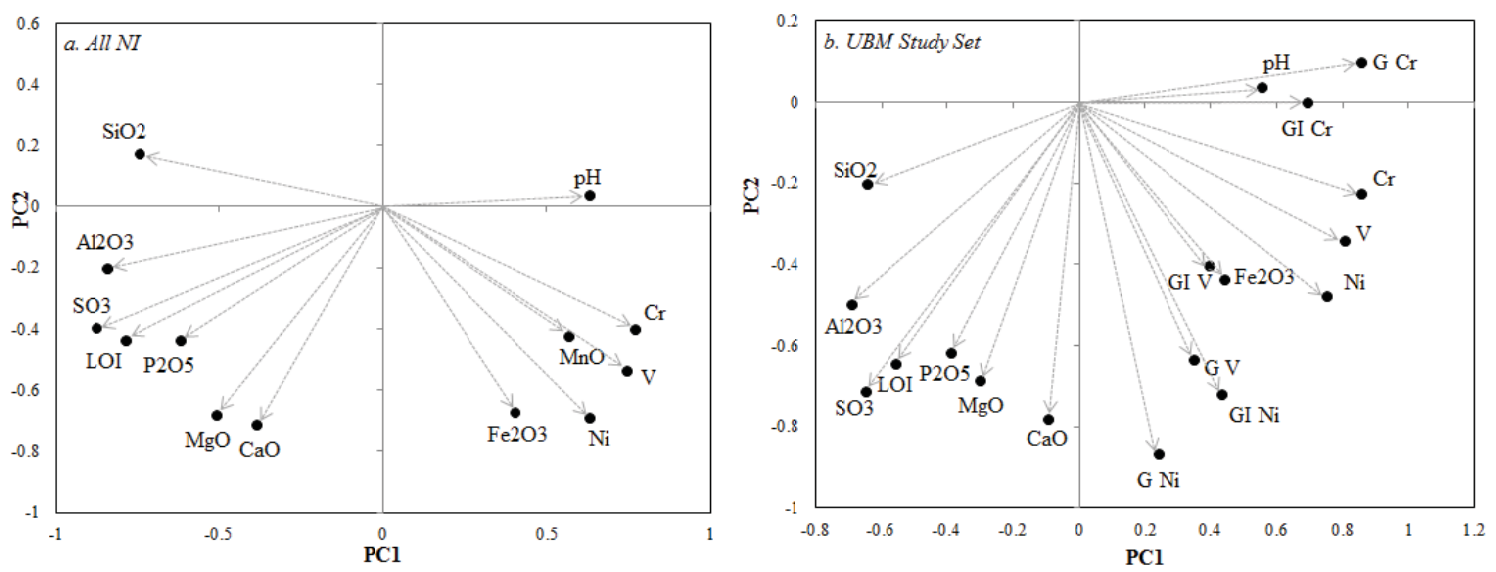

Fig. 9 Eigenvalue factor loading plots for principal components identified in full Northern Ireland geochemistry data set $(a)$ and in UBM study set $(b)$. Acute vector angles imply a correlation between factors while obtuse angles illustrate a negative relationship.

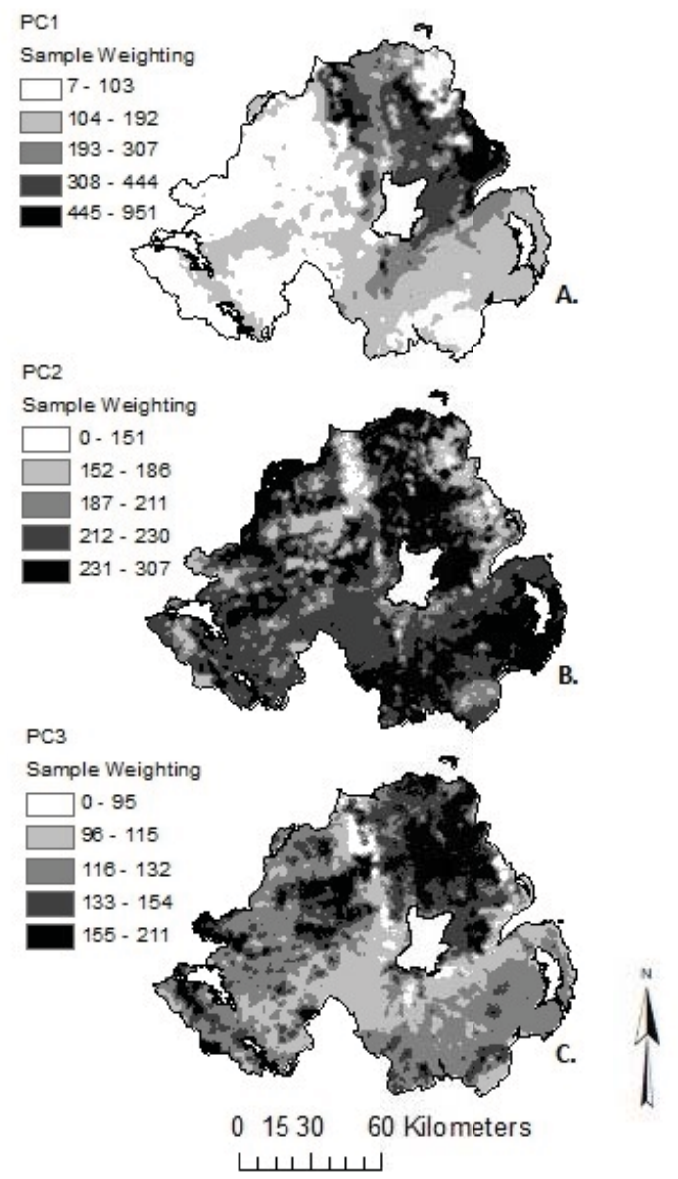

Fig. 10 Mapped soil sample site scores from PCA. First three components account for $87 \%$ of total geochemical variance from thirteen geochemical variables. PC1 is associated with variance from basalt bedrock, PC2 is linked to soil factor variance and remaining variance linked to PC3 is associated predominantly with a $\mathrm{pH}$ influence. 
$\underline{\text { Tables }}$

Table 1. $\mathrm{pH}$ tolerances for prepared digestive fluids.

\begin{tabular}{cccc}
\hline Solution & $\mathrm{pH}$ Tolerance & Solution & $\mathrm{pH}$ Tolerance \\
\hline Saliva & $6.5+/-0.5$ & Duodenal & $7.4+/-0.2$ \\
Gastric & $1.0+/-0.1$ & Bile & $8.0+/-0.2$ \\
\hline
\end{tabular}

Table 2. Summary statistics for trace elements $\left(\mathrm{mg} \mathrm{kg}^{-1}\right)$, major element oxides (\%), $\mathrm{pH}$ and LOI, $n=$ 6,862 (Palmer et al., 2013).

\begin{tabular}{cccccccccccccc}
\hline & $\mathrm{Ni}$ & $\mathrm{V}$ & $\mathrm{Cr}$ & $\mathrm{MgO}$ & $\mathrm{Al}_{2} \mathrm{O}_{3}$ & $\mathrm{SiO}_{2}$ & $\mathrm{P}_{2} \mathrm{O}_{5}$ & $\mathrm{SO}_{3}$ & $\mathrm{CaO}$ & $\mathrm{MnO}$ & $\mathrm{Fe}_{2} \mathrm{O}_{3}$ & $\mathrm{pH}$ & $\mathrm{LOI}$ \\
\hline Min & 1.40 & 5.90 & 4.10 & 0.50 & 3.50 & 13.8 & 0.05 & 0.00 & 0.30 & 0.00 & 0.30 & 2.83 & 1.01 \\
Max & 334 & 402 & 1229 & 5.80 & 17.2 & 87.9 & 1.70 & 2.00 & 16.3 & 15.0 & 42.2 & 7.68 & 98.0 \\
Mean & 46.2 & 99.6 & 131 & 1.45 & 10.6 & 49.6 & 0.26 & 0.18 & 1.15 & 0.08 & 4.65 & 4.74 & 23.4 \\
Median & 29.1 & 85.0 & 94.1 & 1.30 & 11.4 & 54.1 & 0.25 & 0.10 & 0.85 & 0.06 & 4.19 & 4.82 & 12.9 \\
StdDev & 48.7 & 65.0 & 121 & 0.66 & 2.98 & 15.0 & 0.11 & 0.24 & 0.78 & 0.26 & 2.85 & 0.74 & 25.2 \\
\hline
\end{tabular}

Table 3. Geostatistical summary of trace elements, oxides, $\mathrm{pH}$ and LOI. $C_{x}=$ maximum variance accounted for by spatial function, $C_{0}=$ nugget variance not explicable within defined range of spatial function, $a=$ maximum range of spatial dependence between sample locations in meters, Total $C_{x}=$ $C_{0}+C_{1}+C_{2}$. Large $C_{0}$ : Total $C_{x}$ ratios suggest micro-scale processes may influence spatial distributions (Einax and Soldt, 1999).

\begin{tabular}{cccccccc}
\hline Variable & $\mathrm{C}_{0}$ & $\mathrm{C}_{1}$ & $\mathrm{C}_{2}$ & $\mathrm{a}_{1}$ & $\mathrm{a}_{2}$ & Total $\mathrm{C}_{\mathrm{x}}$ & $\mathrm{C}_{0} /$ Total $\mathrm{C}_{\mathrm{x}}(\%)$ \\
\hline $\mathrm{Ni}$ & 262.1 & 756.3 & 1885 & 9038 & 76,595 & 2903 & 9.0 \\
$\mathrm{~V}$ & 697.8 & 1257 & 3014 & 13,816 & 74,194 & 4969 & 14.0 \\
$\mathrm{Cr}$ & 2223 & 11,604 & 3064 & 86,790 & 7038 & 16,891 & 13.2 \\
$\mathrm{MgO}$ & 0.02 & 0.12 & 0.02 & 1029 & 1872 & 0.16 & 12.5 \\
$\mathrm{Al}_{2} \mathrm{O}_{3}$ & 3.46 & 3.40 & 1.86 & 45,354 & 6720 & 8.72 & 39.7 \\
$\mathrm{SiO}_{2}$ & 30.57 & 81.98 & 132.4 & 80,301 & 9927 & 245.0 & 12.5 \\
$\mathrm{P}_{2} \mathrm{O}_{5}$ & 0.006 & 0.004 & -- & 17,233 & -- & 0.01 & 60.0 \\
$\mathrm{SO}_{3}$ & 0.04 & 0.02 & -- & 36,438 & -- & 0.06 & 67.7 \\
$\mathrm{CaO}_{2}$ & 0.32 & 0.51 & -- & 177,902 & -- & 0.83 & 39.5 \\
$\mathrm{MnO}$ & 0.06 & 0.03 & -- & 31,404 & -- & 0.09 & 67.7 \\
$\mathrm{Fe}_{2} \mathrm{O}_{3}$ & 2.71 & 6.86 & -- & 96,708 & -- & 9.57 & 28.3 \\
$\mathrm{pH}$ & 0.27 & 0.09 & 0.29 & 176,782 & 21,738 & 0.65 & 41.5 \\
$\mathrm{LOI}$ & 155.9 & 105.1 & 379.6 & 33,006 & 7886 & 640.6 & 24.3 \\
\hline
\end{tabular}




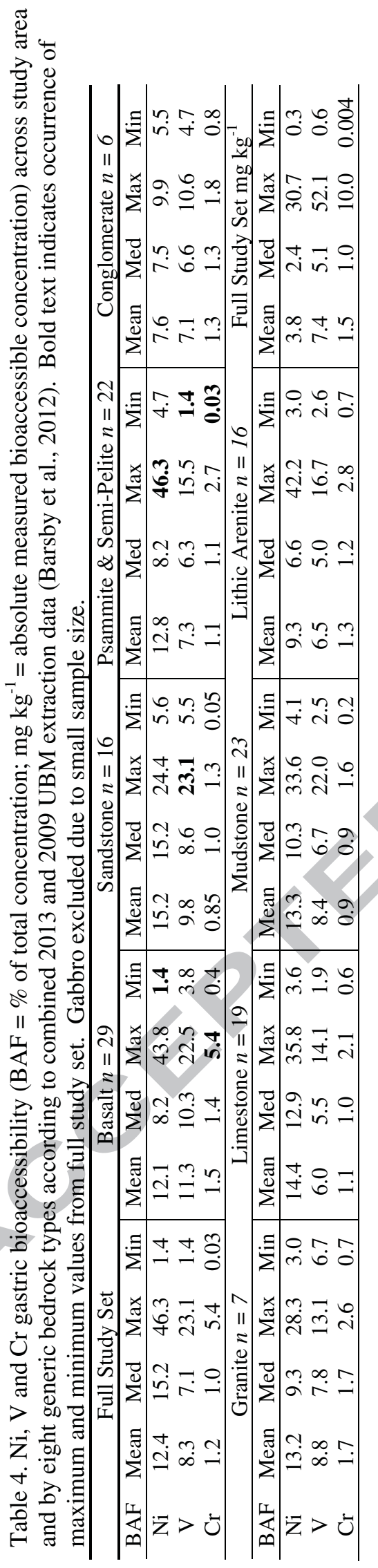


Table 5. Eigenvalues greater than 1 explaining variance for component loadings.

\begin{tabular}{ccccccc}
\hline \multirow{2}{*}{ Component } & \multicolumn{2}{c}{ Value $\%$ Variance } & Cumulative \% & Value & $\%$ Variance & Cumulative \% \\
\cline { 2 - 7 } & \multicolumn{3}{c}{ All Northern Ireland, $n=6862$} & \multicolumn{3}{c}{ UBM Study Set, $n=145$} \\
\hline 1 & 5.87 & 45 & 45 & 6.06 & 34 & 34 \\
2 & 3.13 & 24 & 69 & 5.10 & 28 & 62 \\
3 & 1.34 & 10 & 79 & 1.55 & 9 & 71 \\
4 & -- & -- & -- & 1.46 & 8 & 79 \\
\hline
\end{tabular}

Table 6. Eigenvalue factor loadings for identified principal components in Table 5. MnO not identified as significant variable within UBM study set. Bold values indicate factor is most strongly weighted to indicated component, underlined values show where a large amount of remaining factor variance is accounted for by a secondary component.

\begin{tabular}{|c|c|c|c|c|c|c|c|}
\hline \multirow[t]{2}{*}{ Variable } & \multicolumn{7}{|c|}{ Component } \\
\hline & 1 & 2 & 3 & 1 & 2 & 3 & 4 \\
\hline & \multicolumn{3}{|c|}{ All NI, $n=6862$} & \multicolumn{4}{|c|}{ UBM Study Set, $n=145$} \\
\hline $\mathrm{V}$ & 0.742 & -0.534 & 0.114 & 0.807 & -0.342 & 0.224 & -0.116 \\
\hline $\mathrm{Ni}$ & $\underline{0.631}$ & -0.688 & 0.138 & 0.750 & -0.478 & 0.019 & -0.360 \\
\hline $\mathrm{Cr}$ & 0.770 & -0.399 & 0.136 & 0.857 & -0.224 & -0.087 & -0.175 \\
\hline $\mathrm{MgO}$ & -0.511 & -0.680 & 0.010 & -0.299 & -0.685 & 0.004 & -0.426 \\
\hline $\mathrm{Al}_{2} \mathrm{O}_{3}$ & -0.843 & -0.200 & $\underline{-0.340}$ & -0.689 & $\underline{-0.497}$ & -0.386 & -0.064 \\
\hline $\mathrm{SiO}_{2}$ & -0.747 & 0.174 & $\underline{-0.521}$ & $\underline{-0.646}$ & -0.201 & -0.662 & 0.121 \\
\hline $\mathrm{P}_{2} \mathrm{O}_{5}$ & -0.620 & $\underline{-0.436}$ & -0.362 & -0.388 & -0.617 & $-\underline{-0.430}$ & 0.045 \\
\hline $\mathrm{SO}_{3}$ & -0.875 & $\underline{-0.395}$ & 0.155 & $\underline{-0.649}$ & -0.712 & 0.143 & 0.093 \\
\hline $\mathrm{CaO}$ & $\underline{-0.385}$ & -0.713 & 0.090 & -0.097 & -0.780 & 0.129 & -0.018 \\
\hline $\mathrm{MnO}$ & 0.565 & -0.422 & -0.512 & -- & -- & -- & -- \\
\hline $\mathrm{Fe}_{2} \mathrm{O}_{3}$ & $\underline{0.401}$ & -0.670 & -0.249 & 0.443 & $\underline{-0.435}$ & -0.049 & -0.330 \\
\hline $\mathrm{pH}$ & 0.631 & 0.038 & $\underline{-0.523}$ & 0.555 & 0.036 & $\underline{-0.531}$ & -0.092 \\
\hline LOI & -0.787 & $\underline{-0.438}$ & 0.358 & $\underline{-0.556}$ & -0.644 & 0.436 & 0.089 \\
\hline GV & -- & -- & -- & 0.348 & -0.634 & 0.280 & $\underline{0.512}$ \\
\hline GI V & -- & -- & -- & 0.397 & $\underline{-0.404}$ & -0.127 & 0.765 \\
\hline $\mathrm{GNi}$ & -- & -- & -- & 0.240 & -0.866 & 0.043 & -0.016 \\
\hline GI Ni & -- & -- & -- & 0.433 & -0.719 & -0.193 & -0.077 \\
\hline $\mathrm{GCr}$ & -- & -- & -- & 0.855 & 0.100 & -0.162 & 0.120 \\
\hline GI Cr & -- & -- & -- & 0.691 & -0.001 & -0.219 & 0.283 \\
\hline
\end{tabular}


Highlights

- Two soil-geochemical factors were identified accounting for $69 \%$ of total variance

- Low chromium bioaccessible fractions were linked to basalt bedrock factors

- Bioaccessible nickel was associated with peat and calcareous soil components

- The median vanadium bioaccessible fraction was $7 \%$; chromium $1 \%$ and nickel $15 \%$

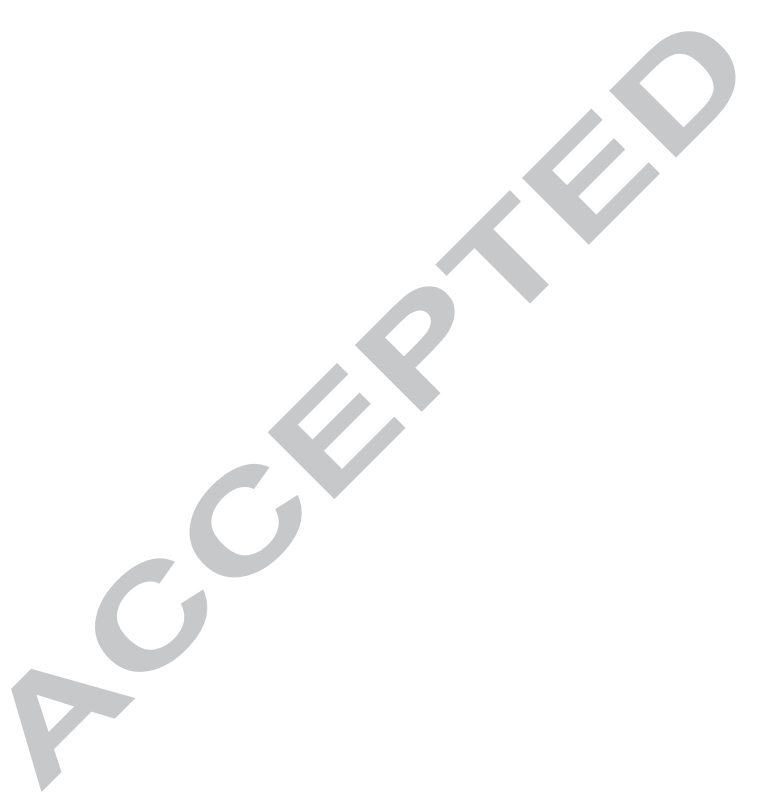

